\title{
Implementation of UPQC Alleviating Power Quality Issues in a Hybrid Grid Integrated System
}

\author{
VAMSI RAM ILLA ${ }^{1}$, RUDRANARAYAN SENAPATI ${ }^{2}$, SARAT CHANDRA SWAIN ${ }^{3}$ \\ $1,2,3$ School of Electrical Engineering, \\ KIIT University \\ Patia, Bhubaneswar, Odisha \\ INDIA
}

\begin{abstract}
The advances in the field of power systems, distribution utilities ordinance the associated non-linear advance loads compliance with the stern power quality (PQ) enhances the reliableness of the delivery system to provide demands of censorious loads and subtle automation systems. Hurdles for sustaining quality power are linked with the continuation of elemental VAR power necessities of loads; voltage dips and swells at the point of common coupling (PCC) due to sudden switching of large industrial loads as well as VAR power indemnifying capacitors and harmonic distortions due to voltage and/or current along with non-linear loads. The harmonic distortions are pertained to be the major drawback the root cause of the PQ issues also the fluctuating pattern by loads causes degradation of voltage waveform which has been presented with variable loads. Hence, custom power device (CPD) materialized as Unified Power Quality Conditioner (UPQC) settles the issue. Intention of the work is to bring spontaneity in both the voltage and current waveform with the Sinusoidal current control strategy (SCCS), a time dominion strategy founded over instantaneous $p q$-theory executed with MATLAB 2016a. The results are well analyzed with proper explanation for selection of the said strategy for the UPQC. As an elementary and inherent strategy, it has titanic prospects further to be applied under photo-voltaic environment associated with a proton exchange membrane fuel cell (FC) in a hybrid grid integrated (HGI) system.
\end{abstract}

Key-Words: - Unified Power Quality Conditioner (UPQC), Custom Power Device (CPD), Distributed Networks (DN), Power Quality (PQ), Sinusoidal Current Control Strategy (SCCS), Fuel Cell (FC), Hybrid Grid Integrated (HGI) system, Irradiance.

Received: May 12, 2021. Revised: November 27, 2021. Accepted: December 12, 2021. Published: December 26, 2021.

\section{Introduction}

Increase in energy demand along with more affinity for power electronics loads results in improvement of performance and reliability in hand. From the statistics of last couple of years, the energy consumption of the developing world has increased @ $5.2 \%$ per annum (p.a.) and especially for India, the per capita depletion has increased @.5\% p.a. results with a concerning issue of malformations in the energy quality needs to overcome by a huge capitalization for efficient production. These days the existing grid is embedded with Distributed Networks (DN) and power electronics controllers to generate clean and efficient electricity. An Indian Electricity Act in 2003 aims to renovate the nation's electricity sector which highlights the issues involving considerable concerns with power quality (PQ) stands as a barrier for energy suppliers, and the authority handling such issues are constantly monitored for good services [1]. The PQ sets norms for measurement affecting the system more economically to make the situation perfect. With the growing use of dynamical PE loads, many significant problems have entered into the equation to mention weak power component, voltage sags/swells, harmonics, etc. This contemplates diversify the sinusoidal supplies preserving uniformity in frequency and magnitude of the RMS parameters in a 3- $\varphi$ device. Again at load end, performance intensification is accomplished with 
implementation technologies for PQ amplification including active filters (AF), Unified Power Frequency Controller (UPFC) or UPQC, etc., configured to persuade boosts in supply quality [2]. In this context UPQC is one of the best options to nullify transients effectively, decreasing the source current harmonics with a rectification of supply power factor. The presence of harmonics in system voltage arises with serious PQ affairs [3-4]. Moreover steady developments in the process to tap energy from Distributed Energy Resources (DER) have detrimental impact on the environment thrives for sustainability with the new buzzwords, i.e., Distributed Networks (DN), Micro Grid (MG), Smart Hybrid Grid (SHG), etc has changed the power market scenario with an urge to maintain the supply quality and faults or interruption free which shapes the power engineers to reconcile for high quality of power with mitigation of system harmonics mostly due to distorted nonlinear loads biasing the supply at a greater extent. [5-7]

Several researches have been carried out in different prospects, e.g., soft computing methods, i.e., Adaptive TABU search [8-12] is implemented for controllers' enhancement, power loss minimization through Particle Swarm Optimization (PSO), Genetic Algorithm (GA), and Neural Network (NN) technique used specifically for optimization of Active Filters (AF). To ensure customer satisfaction CPDs were introduced, i.e., Distributed Static Compensator (D-STACOM), Dynamic Voltage Restorer (DVR), AFs, UPFAC, UPQC, etc., at consumer end under the horde of custom power, i.e., an end user is liable to secure a pre-defined quality power for which CPDs need to work in well coordinated manner [13]. Out of several control strategies these CPDs, a novel and effective Sinusoidal current control strategy (SCCS) has been introduced for UPQC for harmonics mitigation along with other PQ issues due to nonlinear loadings [5]. The efficacy of the methodology has been canvassed with the simulation results contributed on evaluating the Total Harmonic Distortion (THD) of current and voltage in DN environment for SHG.

Problem statement has been stated in Section 2. Concept of CPD and an extensive literature survey has been made in Section 3 and 4. UPQC configuration and Fuel Cell has been provided in Section $5 \& 6$ respectively. The methodology has been illustrated in Section 6 and the results are discussed in Section 7 as well.

\section{Problem Formulation}

Several researches have been carried out in the field of UPQC control which are successfully implemented but are complex and tailor-made and not only increases difficulty level but also not universally implemented for mitigation of all PQ issues in DG environments. This provides an insight into finding a simple and cost effective solution with applicability to distributed networks.

The aim of the investigation is to model and study the application of UPQC based on $p q$-theory for elimination of various characteristic and noncharacteristic harmonics from 3-phase-3-wire (3P3W) system by the application of SCCS with both linear and non-linear loads in DG environment.

\section{Custom Power Devices}

A fundamental classification of CPD can be found in Figure 1.

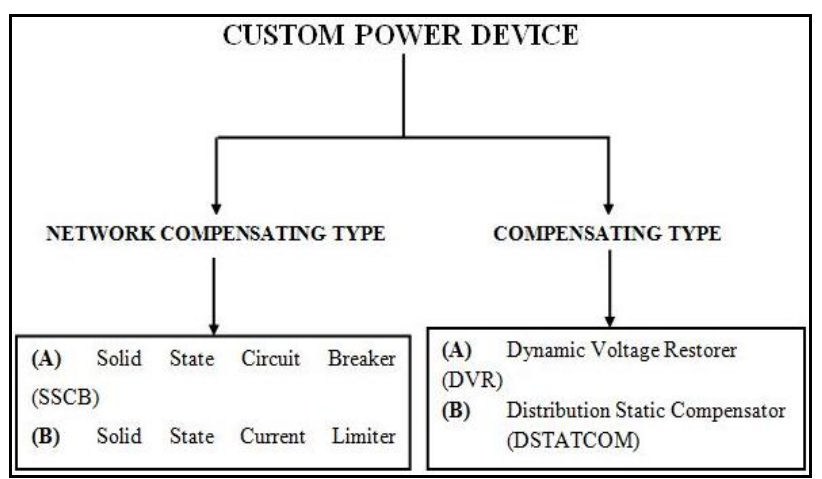

Fig.1. Classification of the CPD

The switchgear is considered as Network compensating type and applied for breaking, limiting and transferring of current, whereas the load compensation is a kind of compensating type of power factor correction, confining of unbalance etc., hence amending the quality of voltage. CPDs are placed in parallel or in series or in combination of both with the main circuit. Several CPDs are available, e.g., DVR, DSTATCOM, UPQC, etc. The interpretation of control technologies where CPDs are involved with consumption of Watt and Var power have been presented in [14].

The objective of Custom Power Park (CPP) dwells with the availability of quality power for them. As vital components of CPD, the DSTATCOM assists in expulsion of unbalance or harmonics, whereas DVR deals with voltage dips or waveform deformities. Subsequently few more CPDs, e.g., Static Compensator (SSSC), Thyristor Control Phase Angle Regulator (TCPAR), Thyristor Controlled Series Compensator (TCSC), Unified Power Flow Controller (UPFC) can be implemented according to their relevancies. FACTS devices, e.g., 
TCPAR, Thyristor Controlled Braking Resistor (TCBR), and Interline Power Flow Controller (IPFC) are casted for flexible power flow in power system. [15]

\section{An Extensive Literature Review}

\subsection{PQ Improvement through CPD}

The PQ has been evolved as the most fruitful phrase for the utilities and power consumers. Therefore power quality has become today's most sensitized area for restructuring of power market. Facets on PQ may be cataloged into different classes of voltage stability, continuity in supply and voltage waveform. There are numerous work have been carried out till date and still continuing by researchers in different prospects.

The notion of CP was first brought into by N. G. Hingorani [16] indicating the use of power electronics controllers in DN enhancing the quality and reliability of the power delivery to consumers who are progressively ambitious of getting a better quality power. Xiaoqing Han et al. [17] have proposed DVR for revision of voltage quality in a microgrid incorporated with photovoltaic (PV) generation/battery units to handle voltage sag or surge improving PQ in microgrid supplying the needed power to the load during voltage sags, swells, and occurrence of interruptions. R. G. Wandhare et al. [18] has proposed hierarchal control technology for hybrid microgrid consisting Photovoltaic (PV), wind turbine, micro-hydro, and fuel cell (FC) based DERs. The most distinguishing characteristic of the suggested control design is the transferability of control between the resource manager and the global microgrid control layer during emergency. Further research was expected with the integration of PQ improvement techniques. M. U. Tomal et al. [19] have investigated the dynamic performance of FC-based DG (FCDG) system. According to them, PQ indicators found for the FCDG meet the standard as per THDv (Total Harmonic Distortion for voltage), but cannot be taken as the sole PQ indicator. Other parameters such as $\mathrm{THD}_{\mathrm{I}}$ (Total Harmonic Distortion for current) may also be considered but no justification has been mentioned. P. Nayak et al. [20] have suggested an authentic model of Kalman Filter (KF) in association with Weighted Kalman Filter (WKF) for absolute tracing of the time-varying harmonics with numerous outputs from the suggested algorithms in microgrid model, but have not addressed the relevance of this technique in gridconnected mode. S. Rafiei et al. [21] proposed an improved minimized order digital adaptive notch filter (DANF) for extraction of the harmonic content with permitting compensation of either a specific frequency or a range of frequencies in the spectral content of the injected current having a demerit of discrimination of harmonic elimination. A. Shahid et al. [22] have used Droop control type modular approach for power-sharing and tried to minimize the system level harmonic content with poor harmonic sharing property to be a bit unsuitable technique for much consideration about harmonic elimination.

S. Dhar et al. [23] have proposed islanding detection technique established on the variation of negative sequence Watt and VAR power at coupling bus as a combo of active and passive islanding detection technique. To accomplish faster tracking along with negligible non-detection Zone (NDZ), a local Voltage Source Converter (VSC) control with negative sequence power injected through high overshoot. The author has designed the threshold filter to avoid false detection by Binary Tree (BT) and claimed as one of the auspicious islanding detection strategy respecting the fast run on time and negligible NDZ, but failed to address the effect of islanding on PQ which has been discussed by S. $K$. Khadem et al [24]. R. Effatnejad has investigated the complementary theory-based control algorithm for the design of the shunt active filter (ShAF) for PQ improvement and frequency control with more focus on inverter control rather on PQ aspects [25]. R. R. Shankar et al. [26] have emphasized over the series implementation of VSC tied with the grid mitigating voltage sags and swells with the dual vector current controller. With the space vector pulse width modulation (SVPWM), switching pulses for the VSC were generated to mitigate sag and swell, but have not addressed the other PQ issues like power factor improvement, harmonic elimination, etc. R. W. Mosobi et al. [27] have presented design and analysis of PQ for an integrated DER for power supplies to communities at remote locations. Their proposed integrated DG model has a PV, a wind energy system (WES) and a micro-hydro system (MHS) to meet load demand. For reactive power compensation, STATCOM has been proposed to improve PQ of the system through a 3- $\varphi$ IGBT built on current controlled voltage source inverter (CC-VSI) by self-supported DC bus, but lacks with proper explanation for selection of CC-VSI. Again, use of STATCOM is suited for voltage related PQ issues of DN on the load end but fails to perform at source end.

Now it is clear about unworthiness in using passive filters for harmonic elimination and resolving PQ issues due to its demerits of harmonic 
resonance and amplification but relies absolutely on the source and line impedance as well as unsettled load parameters. To alleviate these issues, the AFs with power electronic devices and employment of FACTS concepts as a whole result a unique compensating device, i.e., UPQC.

\subsection{UPQC}

V. Khadkikar et al. [28] have analyzed the working of UPQC in zero real power exhaustion, assimilation and distribution. The Series Active Filter (SeAF) as a part of UPQC performs in active power distribution and assimilation during subsequent voltage dip and swells conditions whereas the Shunt Active Filter (ShAPF) as a part of UPQC assists SeAF through DC link voltage at a fixed value. V. Khadkikar et al. [29] have conferred a 1- $\varphi$ UPQC to sort out PQ issues in 1- $\varphi$ systems. It has been observed that distorted supply results a THD of $14.1 \%$ accompanying a non-linear load processed with a disfigured current (THD of $30.98 \%$ ). The UPQC as a whole repay these harmonics ensuing sinusoidal supply current (THD of $3.77 \%$ ) and load voltage (THD of $2.54 \%$ ). The THD attained by them was satisfactory and could have been further improved. Besides, the applicability of this technique fails for 3- $\varphi$ system. V. Khadkikar et al. [30] have suggested the steadystate investigation of UPQC where the mathematical investigation has been established with Watt and Var power circulation through ShAPF and SeAF; however, the SeAF can engross or distribute the true power and hence the need of Var power is solely controlled by ShAPF in every condition. RVD Ram Rao et al. [31] have discussed the various factors affecting the PQ, e.g., harmonic defilement for nonlinear loads, rectifiers, voltage and current fluttering because of arc in furnaces, dip and swell with switching of loads, etc. According to him the authors, UPQC is a blend of shunt and series active filter connected back-to-back, compensating the supply voltage and the load current concurrently or mitigating all sorts of voltage and current variation power factor correction in the DN. D. O. Kisck et al. [32] have proposed an optimized UPQC, which aims at minimum VA loading of the UPQC. H. Fujita et al. [33] has made comparison among the three types of control methods (current detection method, voltage detection method and combined method). M. Vilathgamuwa et al. [34] have designed UPQC by state-space-averaging technique to evaluate its performance of the ShPF by moving time window method. Y. Chen et al. [35] have discussed the theory and modeling of UPQC as a FACTS device. M. Hu et al. [36] have proposed the mathematical model based on switching function and analyzes the control techniques of such UPQC and validated the results through simulation, but have not mentioned the applicability and challenges of implementation of UPQC in Distributed Generation (DG)-environment. A. Elnady et al. [37] have proposed new functionalities (i.e., different voltage sags mitigation) for UPQC specifically voltage sag mitigation by UPQC, whereas other functions have not been highlighted. Again it is silent about harmonic issues just highlighting on fault conditions. M. Basu et al. [38] have come up with a new technique of UPQC-Q, which is based on quadrature injection of voltage prior to the supply current, to restrict the real power consumption by the series compensator at steady state highlighting voltage profile improvement, but does not allow mitigation of unbalancing conditions. M. T Haque et al. [39] have suggested a control technique, where the combined concept of extended $p q$-theory and instantaneous symmetrical components theory for shunt and series inverter. R. Faranda et al. [40] have proposed a compensation strategy to limit the switching losses in UPQC. G. Jianjun et al. [41] have integrated the SAF and ShAPF to regulate any voltage imbalance at the PCC. L. H. Tey et al. [42] have proposed ANNbased control technique for UPQC for alleviation of PQ issues including harmonics in the DN. Timedomain based derivation method is used to evaluate the harmonic content in the load current and source voltage. The proposed topology establishes two 3- $\varphi$ PWM-VSIs controlled by Levenberg-Marquardt Back Propagation (LMBP) ANN techniques filters out the harmonics from the utility without compromising the system stability. J. M. Corrêa et al. [43] have proposed a controller based on the instantaneous $p q$-theory to 1- $\varphi$ UPQC for high frequency AC-based microgrid systems A. Ghosh et al. [44] have proposed control technique for inverter using output feedback control which moves the poles of the open loop system radially towards the centre producing a variable switching frequency control action. L. Monteiro et al. [45] have proposed Sinusoidal Fryze Current Control Strategy for UPQC which uses synchronizing circuit (PLL control circuit), used in 3- $\varphi-3-$ Wire systems to promote a dual control strategy for SAF through an additional PLL circuit which is not the case in the SCCS. A. Nasiri et al. [46] have discussed three topologies of 1- $\varphi$ UPQC introducing two reduced parts consisting of 2 or 3 legs instead of four legs. G. Chen et al. [47] have proposed a UPQC with One Cycle Control (OCC) with an advantage of vector operation for minimizing losses. Tey et al. [48] have 
suggested a Linear Quadratic Regulator control technique for UPQC control.

A. Ghosh et al. [49] have studied UPQC operation for bus voltage regulation of critical loads under unbalance, harmonics, voltage dip/swell and other interferences in power delivery system. V. Khadkikar et al. [50] have suggested a control technique for UPQC based on unit vector template generation to mitigate the voltage harmonics exist in the utility voltage. C. A. Sepulveda et al. [51] have proposed Lyapnuov Linearization Method (LLM) based control strategy for UPQC. M. Aredes et al. [52] introduced a prototype model of UPQC, with a digital control technique based on the instantaneous power theory ( $p q$-theory). However many control theory based on instantaneous $p q$-theory have been proposed in [53-55]. J. R. Reyes et al. [56] have worked on 1- $\phi$ UPQC which is commonly used in DG-environment, with an issue of limited scope at the time of need for 3- $\phi$ supply. A. Kazemi et al. [57] have introduced the application of Adaptive Noise Canceling (ANC) theory in 1- $\phi$ UPQC. Several other notable works are given in [58-63]. V. Khadkikar et al. [58] have measured the execution of UPQC in a complex DN with genuine variables. A. J. Laxmi et al. [59] have developed an appropriate design of different controllers based on Fuzzy inference system, ANN and the conventional PI controller for the UPQC. I. Axente et al. [62] have proposed a control strategy to avoid stability issues due to the use of hysteresis control technique in the ShAPF by using an LCL filter in the shunt component of UPQC. M. Vilathgamuwa et al. [34] have presented the PQ improvement of a sensitive load by a UPQC acting as a power conditioner uses state-space-averaging technique for its performance analysis. Y. Chen et al. [35] have proposed a UPQC consisting of a thyristor controlled capacitor banks, SAF and ShAPF. G. Jianjun et al. [64] have proposed a novel control strategy which not only compensates VAR power, negative sequence current, and harmonics generated by a non-linear load, but also any voltage imbalance appearing at PCC through a laboratory prototype of $20 \mathrm{KVA}$ to confirm the practicality and efficacy of the suggested UPQC. J. N. Ganesh et al. [65] have proposed a discrete-time feedback inverter control strategy of pole shifting that moves the open-loop system poles towards the origin. In the time domain, control is simpler and continuous, as in case of the SCCS.

Several researches have been made on pqrinstantaneous power theory. According to $\mathrm{F}$. $\mathrm{Ng}$ et al. [66] the $p q r$ - theory transforms a $3-\Phi$ voltage space vector into a two mutually perpendicular quantities corresponding real power and imaginary power. A corresponding $r$-axis component is added to force the reference current over the $\alpha \beta$-plane. $\mathrm{M}$. T. Haque et al. [67] have proposed Fourier Transform based control strategy for ShAPF and SAF which uses positive sequence detection. According to M. Hojo et al. [68], dynamic voltage restoration can be achieved by the utilization of the UPQC-L, which helps to limit the fault current.

From the comprehensive literature review over UPQC by various authors, it can be inferred that mitigation of PQ issues is a budding challenge and UPQC possesses enough capability to mitigate them. A simple technique with better performance is the need of the hour. This gives engineers scope to implement a cheaper control for UPQC which will address the issues of the DG environment.

\section{UPQC Configuration}

Figure 2 is the proposed block diagram of UPQC comprising of shunt and series converters, low and high pass filters, DC link capacitor, coupling transformer and a pulse generator.

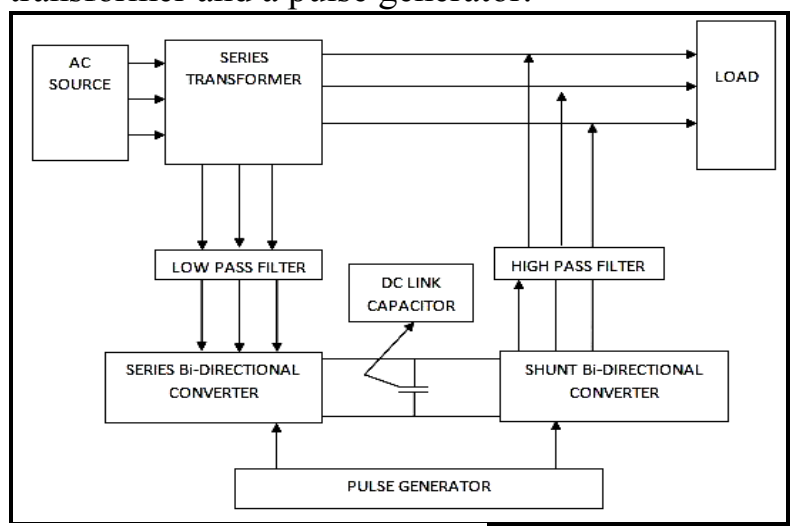

Fig.2. Block diagram of UPQC

In the schematic diagram (Fig.3) of VSI based UPQC topology, the shunt inverter is responsible for the necessary harmonic currents for the load whereas the Var power is responsible for power factor and voltage profile improvement.

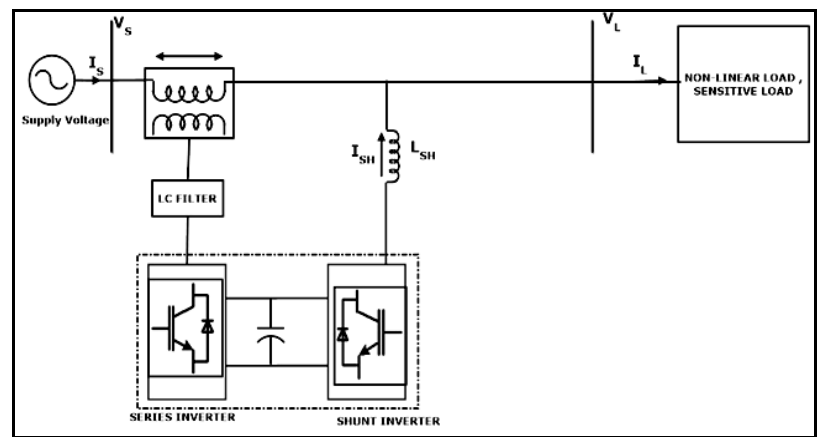

Fig.3. Schematic Diagram of UPQC 
Additionally, shunt coupling inductor marked by $L_{s h}$, acts as a link between the shunt inverter and the load circuit. A coupling transformer of proper turns ratio is used in the series inverter circuit to minimize the kVA rating abdicating the current. [69-71]

\section{Fuel Cell}

Fuel cells (FC) can be termed as a typical electrochemical instrument which directly converts chemical power into electric power. The various types of FC are classified by electrolyte because they classify main features such as the temperature of operation, power-up time, size of the stack, migratory ion and the collision resistance. The general utilization of FC is for the alternative generation of power. The reaction of oxygen, electron and ion near anti-anode by other catalyst produces water and other products. The classification of FC is made by the electrolyte used and by the various range of starting-up time ranges from $1 \mathrm{sec}$ to $10 \mathrm{~min}$. The overall efficiency of FC ranges between $40 \%-60 \%$. [72]

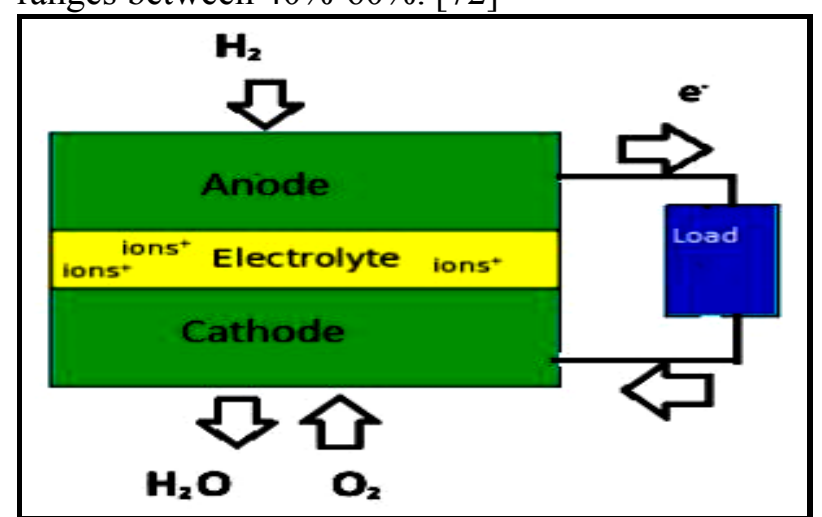

Fig.4 Basic block diagram of FC

\section{Methodology}

There has been multiple control strategies suggested that necessarily require precise design and analytical integration with hardware uncertainties. In accordance with different renewable alliances, any ambiguity from the failure of control devices will lead to the islanding state and other cascading effects. Furthermore, SCCS has been ratified to lessen ambiguity in design and budget constraints [73-74]. This technique results in regulation of the line current harmonic in $p q$-frame. It transforms line currents of the 3- $\Phi-3-W$ network into 2- $\varphi$ mutually independent components for a proper hold over the network comprising of ShAF and SeAF control retaining DC-link capacitor voltage. The ShAF compensates the non-sinusoidal load current and SeAF compensates the load voltage [75-76]. For effective compensation, zero sequential power is carried into $\alpha \beta 0$-reference frame.
Mathematically:

$$
\left[\begin{array}{c}
p_{0} \\
p \\
q
\end{array}\right]=\left[\begin{array}{ccc}
v_{0} & 0 & 0 \\
0 & v_{\alpha} & v_{\beta} \\
0 & v_{\beta} & -v_{\alpha}
\end{array}|| \begin{array}{c}
i_{0} \\
i_{\alpha} \\
i_{\beta}
\end{array}\right]---------(1)
$$

Instantaneous 3- $\varphi$ Watt power is:

$P_{3-\varphi}=v_{\alpha} i_{\alpha}+v_{\beta} i_{\beta}$

Whereas

$p=\bar{p}+p-$

From (3), the Watt power has two components of desire power and instantaneous actual power. The desire power is the mean of instantaneous real power as referred in a balanced way in per unit time through $a-b-c$ frame. The theoretical power measured of an instant will be:

$q=v_{\beta} i_{\alpha}-v_{\alpha} i_{\beta}=\frac{1}{\sqrt{3}}\left(v_{a b} i_{c}+v_{b c} i_{a}+v_{c a} i_{b}\right)-----(4)$

$\left[i_{a}, i_{b}, i_{c}\right.$ and $v_{a}, v_{b}, v_{c}$ are current and voltage of an instant in $a b c$ frame whereas $i_{\alpha}, i_{\beta}, i_{0}$ and $v_{\alpha}, v_{\beta}, v_{0}$ are current and voltage of an instant in $\alpha \beta 0$-frame respectively].

The active and reactive current components are:

$\left[\begin{array}{l}i_{\alpha} \\ i_{\beta}\end{array}\right]=\frac{1}{v_{\alpha}^{2}+v_{\beta}^{2}}\left[\begin{array}{cc}v_{\alpha} & v_{\beta} \\ v_{\beta} & -v_{\alpha}\end{array}\right]\left[\begin{array}{l}p \\ 0\end{array}\right]+\frac{1}{v_{\alpha}^{2}+v_{\beta}^{2}}\left[\begin{array}{cc}v_{\alpha} & v_{\beta} \\ v_{\beta} & -v_{\alpha}\end{array}\right]\left[\begin{array}{l}0 \\ q\end{array}\right]-$

Hence by Inverse Clarke Transformation:

$\left\lfloor\begin{array}{l}i_{a(p)} \\ i_{b(p)} \\ i_{c(p)}\end{array}\right\rfloor=\sqrt{\frac{2}{3}}\left[\begin{array}{cc}1 & 0 \\ -1 / 2 & \sqrt{3} / 2 \\ -1 / 2 & -\sqrt{3} / 2\end{array}\right] \frac{v_{\alpha} i_{\alpha}+v_{\beta} i_{\beta}}{v_{\alpha}^{2}+v_{\beta}^{2}}\left[\begin{array}{c}v_{\alpha} \\ v_{\beta}\end{array}\right]--(6)$
$\left\lfloor\begin{array}{l}i_{a(q)} \\ i_{b(q)} \\ i_{c(q)}\end{array}\right\rfloor=\frac{v_{a b} i_{c}+v_{b c} i_{a}+v_{c a} i_{b}}{v_{a b}^{2}+v_{b c}^{2}+v_{c a}^{2}}\left[\begin{array}{c}v_{b c} \\ v_{c a} \\ v_{a b}\end{array}\right]---(7)$

For line voltage free from zero sequence components,

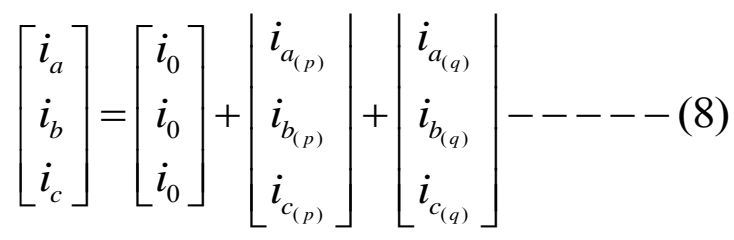

\subsection{SCCS for ShAF}

Figure 5 is the control mechanism for the $3-\Phi-3-W$ system shunt inverter. 


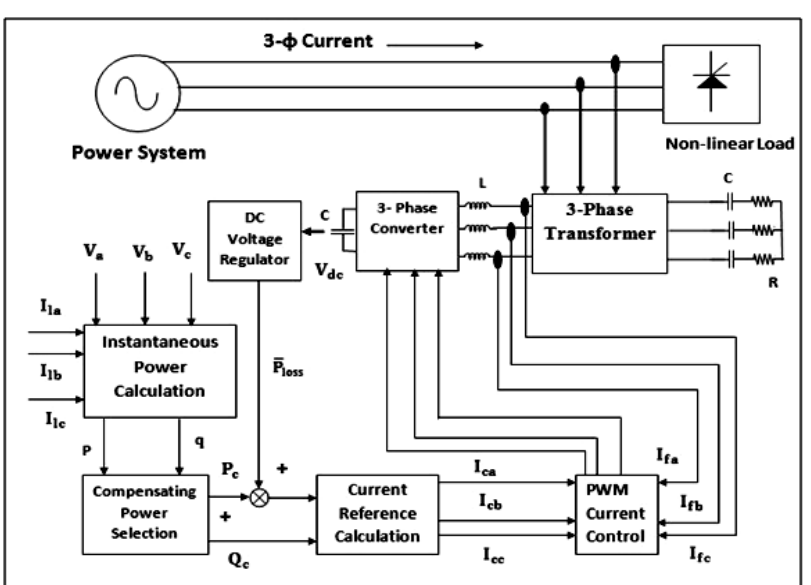

Fig.5. Shunt Inverter Control of 3-Ф-3-W System

The ShAF draws specific power from the input at an instant and offsets the oscillating real power $(\tilde{p})$. The active filter capacitor (AFC) aligned in parallel to the circuit compensates the zero sequence and real power [77]. The 3- $\phi$ to $2-\phi$ voltage conversion is accomplished with Clarke transformation. Equation (9) estimates Watt and Var power with 2- $\phi$ current $i_{\alpha}, i_{\beta}$ in the power estimation module.

$\left[\begin{array}{l}v_{0} \\ v_{\alpha} \\ v_{\beta}\end{array}\right]=\sqrt{\frac{2}{3}}\left[\begin{array}{ccc}1 / \sqrt{2} & 1 / \sqrt{2} & 1 / \sqrt{2} \\ 1 & -1 / 2 & -1 / 2 \\ 0 & \sqrt{3} / 2 & \sqrt{3} / 2\end{array}\right]\left[\begin{array}{l}v_{a}^{\prime} \\ v_{b}^{\prime} \\ v_{c}^{\prime}\end{array}\right]-----(9)$

The outline of the AFC for SCCS is shown in Fig. 6.

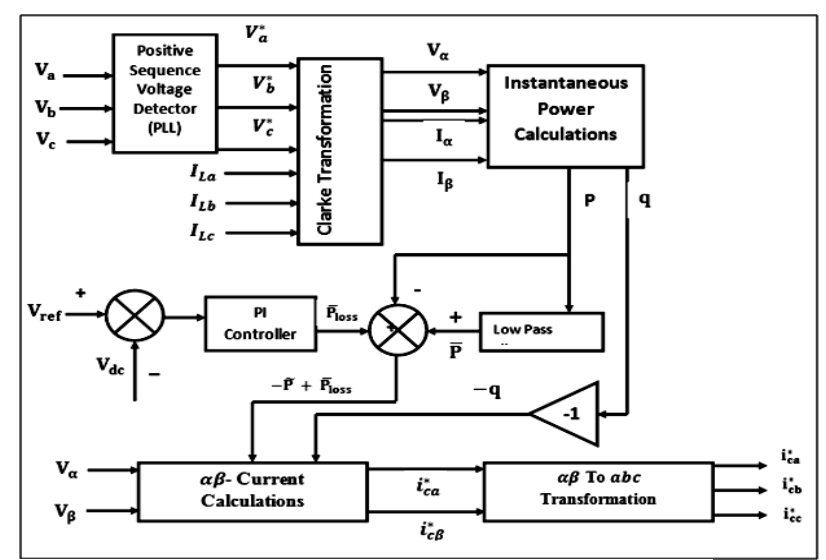

Fig.6. Control block of SCCS with 3- $\varphi$ ShAF

Similarly, Clarke Transformation converts $3-\varphi$ line current to 2- $\phi$ and estimates true and complex power and 2- $\phi$ voltage $\left(v_{\alpha}^{\prime}, v_{\beta}^{\prime}\right)$.

$\left[\begin{array}{l}i_{0} \\ i_{\alpha} \\ i_{\beta}\end{array}\right]=\sqrt{\frac{2}{3}}\left[\begin{array}{ccc}1 / \sqrt{2} & 1 / \sqrt{2} & 1 / \sqrt{2} \\ 1 & -1 / 2 & -1 / 2 \\ 0 & \sqrt{3} / 2 & \sqrt{3} / 2\end{array}\right]\left[\begin{array}{l}i_{a} \\ i_{b} \\ i_{c}\end{array}\right]-----(10)$

The phase voltage and line current of an instant are obtained from zero-sequence component, Watt $(p)$ and $\operatorname{Var}(q)$ power components: $\left[\begin{array}{c}p_{0} \\ p \\ q\end{array}\right]=\left[\begin{array}{ccc}v_{0} & 0 & 0 \\ 0 & v_{\alpha}^{\prime} & v_{\beta} \\ 0 & v_{\beta} & -v_{\alpha}^{\prime}\end{array}\right]\left[\begin{array}{l}i_{0} \\ i_{\alpha} \\ i_{\beta}\end{array}\right]-----$

Hence the Watt and Var power will be:

$$
p=v_{\alpha}^{\prime} \cdot i_{\alpha}+v_{\beta}^{\prime} \cdot i_{\beta}----------(12)
$$$$
q=v_{\beta}^{\prime} \cdot i_{\alpha}+v_{\alpha}^{\prime} \cdot i_{\beta}----------(13)
$$

The nonlinear load leads to mandatory measurement of true power and is classified into average $(\bar{p})$ as per shunt current compensation and the oscillating component $(\tilde{p})$ of an instant related as:

$$
p_{c}=\tilde{p}=p-\bar{p}------(14)
$$

In a real practice, the division can be achieved by choosing low pass filter (LPF) to cover the power block with the help of cutoff frequency resulting in the compensation of transient error.

Hence the balanced imaginary power is:

$-q=-\bar{q}+\tilde{q}-------(15)$

\subsection{SCCS for CAF}

The suggested procedure applied to a 3- $\Phi-3-\mathrm{W}$ device, is performed by the SCCS on SeAF's instant theory. A 3P3W SeAF block diagram for voltage compensation has been shown in Fig. 7.

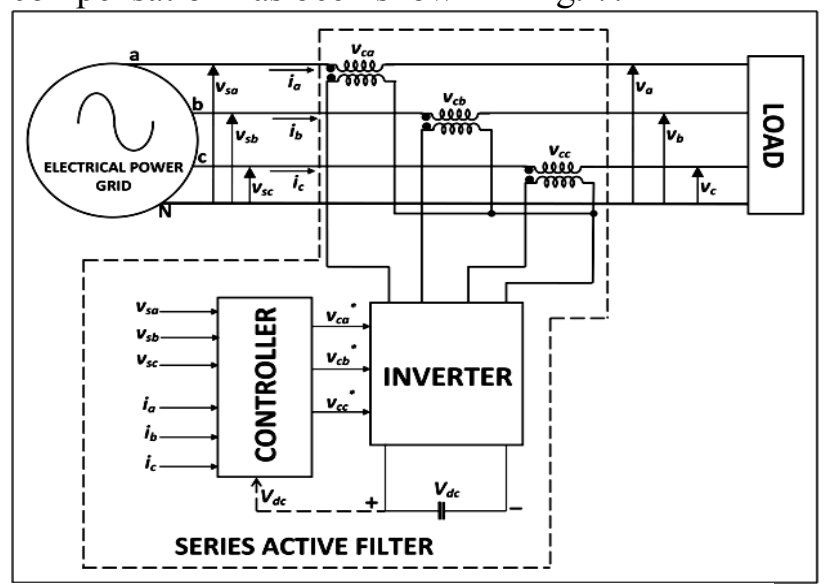

Fig.7. Series Inverter Control of 3- $\Phi-3-W$ System

SeAF boosts energy waveforms with consideration of zero-sequence, the correlation among the source, load and $\mathrm{AF}$ voltages shall be as follows:

$$
\left\lfloor\begin{array}{l}
v_{s a} \\
v_{s b} \\
v_{s c}
\end{array}\right\rfloor=\left\lfloor\begin{array}{l}
v_{a} \\
v_{b} \\
v_{c}
\end{array}\right\rfloor-\left\lfloor\begin{array}{l}
v_{C a} \\
v_{C b} \\
v_{C c}
\end{array}\right\rfloor-------(16
$$

Three separate 1- $\Phi$ converters with customary dc capacitor mingle with the critical SeAF voltages. The reference voltage is assessed with the supply to AFC and input signals, i.e., load voltages and source currents. The $p q$-theory calculates the voltages implying known variables like voltage, currents, and true and complex powers elements defined during 
involvement of series voltage compensation as dual of shunt current compensation. [78]

$$
\left[\begin{array}{c}
p_{0} \\
p \\
q
\end{array}\right]=\left[\begin{array}{ccc}
i_{0} & 0 & 0 \\
0 & i_{\alpha} & i_{\beta} \\
0 & -i_{\beta} & i_{\alpha}
\end{array}\right]\left[\begin{array}{c}
v_{0} \\
v_{\alpha} \\
v_{\beta}
\end{array}\right]------(17
$$

The above condition causes true power $(\tilde{p})$ and complex power $(\tilde{q})$ with zero sequence component to oscillate and perceived as zero. The sinusoidal voltages to be incorporated with the SeAF, together with the oscillating powers, for load harmonic voltage mitigation by using:

$\left\lfloor\begin{array}{c}v_{C \alpha}^{*} \\ v_{C \beta}^{*}\end{array}\right\rfloor=\frac{1}{i_{\alpha}^{2}+i_{\beta}^{2}}\left[\begin{array}{cc}i_{\alpha} & -i_{\beta} \\ i_{\beta} & i_{\alpha}\end{array}\right]\left[\begin{array}{c}\tilde{p} \\ \tilde{q}\end{array}\right]-------(18$

A specific calculation of $\Delta \bar{p}$ is applied to $\tilde{p}$ with an aim for loss compensation. The reference voltages $v^{*}{ }_{C_{a}}$ and $v^{*}{ }_{C_{b}}$ need to be converted to $a b c-$ reference by:

$\left[\begin{array}{l}v^{*}{ }^{*} C_{a} \\ v^{*}{ }^{*} C_{b} \\ v^{*} C_{c}\end{array}\right]=\sqrt{\frac{2}{3}}\left[\begin{array}{ll}1 & 0 \\ -1 / 2 & \sqrt{3} / 2 \\ -1 / 2 & -\sqrt{3} / 2\end{array} \mid\left[\begin{array}{l}v^{*}{ }^{*} \\ v^{*}{ }^{*} C_{\beta}\end{array}\right]------(19)\right.$

For harmonic load voltage stabilization, the SeAF generates the voltage as per (19). The strategy confirms maximum sinusoid for source voltage [79]. The network under evaluation comprises of SCCSbased UPQC accustomed to eliminate the PQ issues in the hybrid grid integrated (HGI) system. The belief behind using of SCCS is its uniqueness in simplicity and cost effectiveness among all control techniques for PQ mitigation [80-83]. The suggested approach for the HGI system based on PQ progression by UPQC with an output provided to boost converter.

\section{SIMULATION RESULT}

\subsection{UPQC with Grid Integrated Non-linear Load}

The system embraces with UPQC for PQ improvisation of a HGI system feeding non-linear load. The UPQC considered here is based on SCC circuitry feeding a converter-fed resistive load. The execution of UPQC for the 3- $\varphi$ 3-Wire system simulated through MATLAB Simulink 2016a software with simulation variables of Table-1.

Table-1: SIMULATION PARAMETER

\begin{tabular}{|l|l|}
\hline Load Variables & Values \\
\hline Non-Linear Load & \\
\hline Resistance (R) & $100 \Omega$ \\
\hline
\end{tabular}

\begin{tabular}{|l|l|}
\hline Inductance (L) & $150 \mu \mathrm{H}$ \\
\hline Linear Load & \\
\hline Phase-to-Phase Voltage (V) & $1 \mathrm{kV}$ \\
\hline Watt Power (P) & $0.01 \mathrm{MW}$ \\
\hline Var Power (Q) & $0.1 \mathrm{kVAR}$ \\
\hline DC Link Capacitance (C) & $0.001 \mathrm{~F}$ \\
\hline
\end{tabular}

The source voltage is $25 \mathrm{kV}$ peak value. In the first 0.1 second, before the circuit breaker $(\mathrm{CB})$ is open, due to the inception of the load there is a sudden fall in voltage. After closing of the CB, ShAPF starts with the operation injecting with the required reactive power bringing the voltage to the desired level.

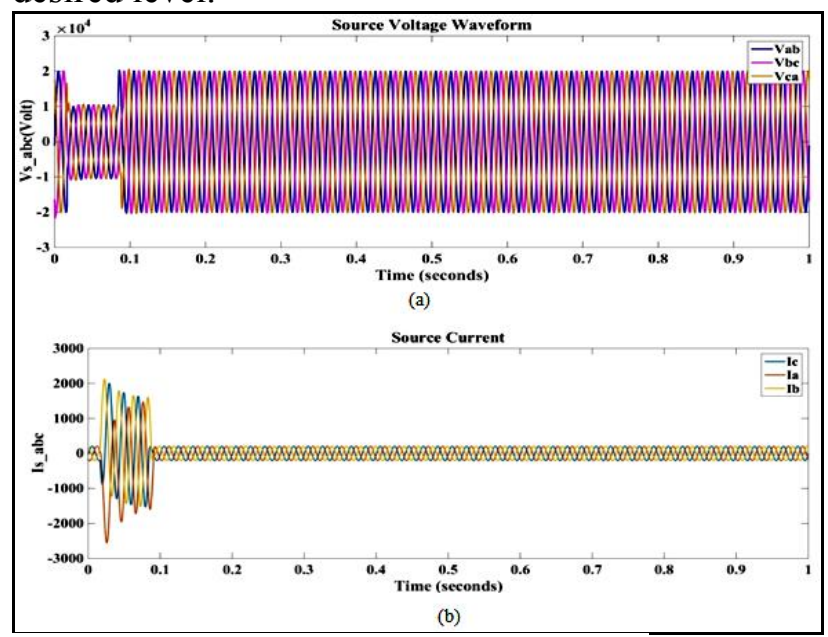

Fig.8. Utility end: (a) Voltage (b) Current

There is a switching delay of 0.1 second provided for the series converter. Till the series converter is not in operation, there is a voltage dip. The ShAPF improves the current profile supplying the harmonic power indicating the compensation of the disturbances at source side by the UPQC.

The THD in the source current has been obtained from the FFT analysis and is found as $0.3 \%$ (Figure 9).

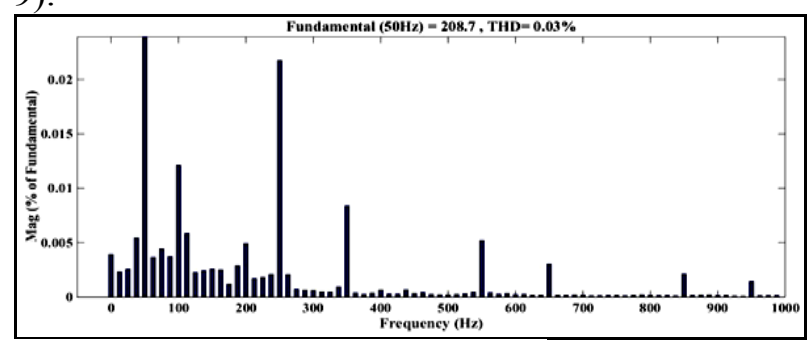

Fig.9.THD level in Source Current

Use of the UPQC based on SCCS balances the end voltage and source current, and makes them smooth (Figure 10 (a) and (b)).

During the switching of load there is a voltage dip. Due to the intervention of shunt converter control, the voltage is brought back to the desired level after 0.1 second, as observed in Figure 10. 


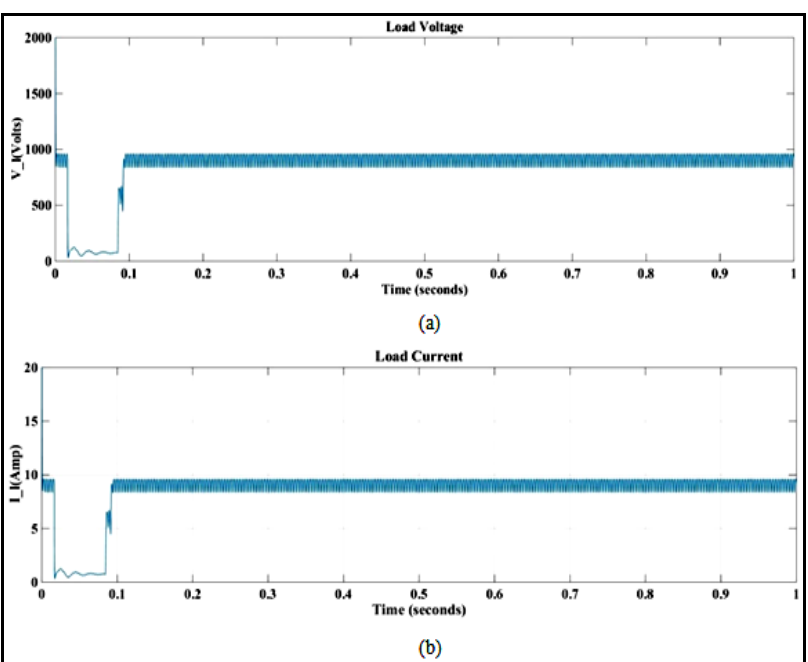

Fig.10. Load-end results: (a) Load voltage (b) Load current

Here UPQC operated in grid integrated PV system, PV-battery-FC system; PV-battery isolated conditions are simulated for a 3- $\varphi$ 3-Wire system by MATLAB $\backslash$ SIMULINK 2016a. The control circuitry for 3- $\varphi$ 3-Wire is designed for grid-tied PV systems both in stand-alone and integrated mode for the given parameters in Table-2.

Table-2: SIMULATION PARAMETERS

\begin{tabular}{|l|l|}
\hline Variables & Value \\
\hline $\begin{array}{l}\text { Boost Converter Operating } \\
\text { Frequency }\end{array}$ & $5 \mathrm{kHz}$ \\
\hline DC-Link Capacitance & $0.001 \mathrm{~F}$ \\
\hline Phase-to-Phase Voltage & $0.415 \mathrm{kV}$ \\
\hline Linear Watt Power & $0.01 \mathrm{MW}$ \\
\hline Linear VAR Power & $100 \mathrm{VAR}$ \\
\hline Resistance of Rectifier Load & $60 \Omega$ \\
\hline Inductance of Rectifier Load & $150 \mu \mathrm{H}$ \\
\hline
\end{tabular}

7.2 Integrated Hybrid System without UPQC The performance UPQC excluded grid-integrated PV-Battery-FC system has been exemplified.

Phase wise grid injected voltages and behaviour of grid injected current for 3- $\varphi$ 3-Wire HGI system are demonstrated in figure 11(a) and (b) respectively.

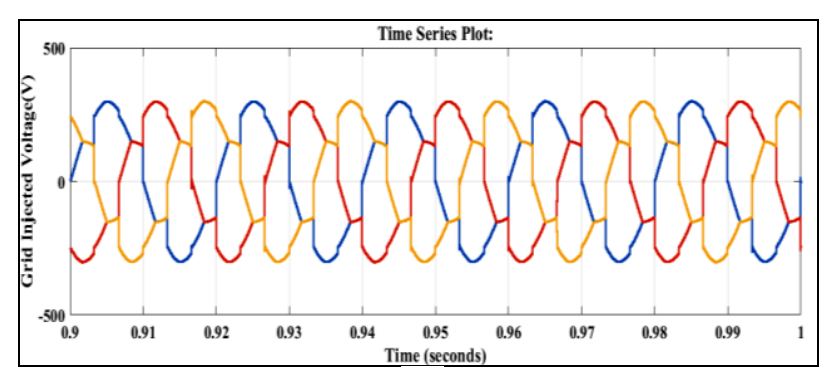

(a)

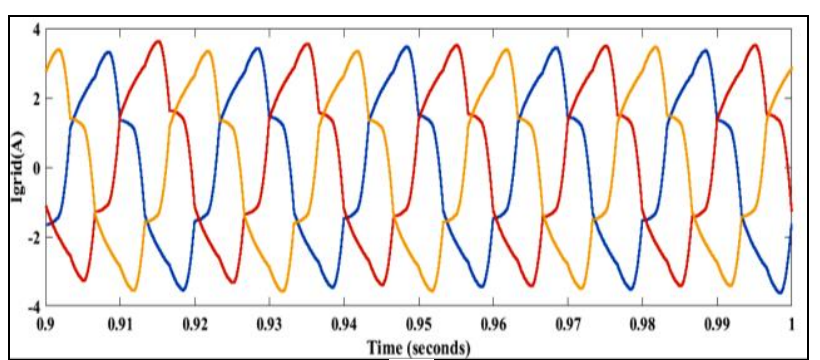

(b)

Fig.11. Grid injected source: (a) voltage, (b) current

The UPQC excluded voltage and current waveforms are non-sinusoidal owing to non-linear load. The FFT analysis of grid injected current has an RMS value of 3.154 A with a THD of 0.1466 or $14.66 \%$ of the fundamental (Fig. 12).

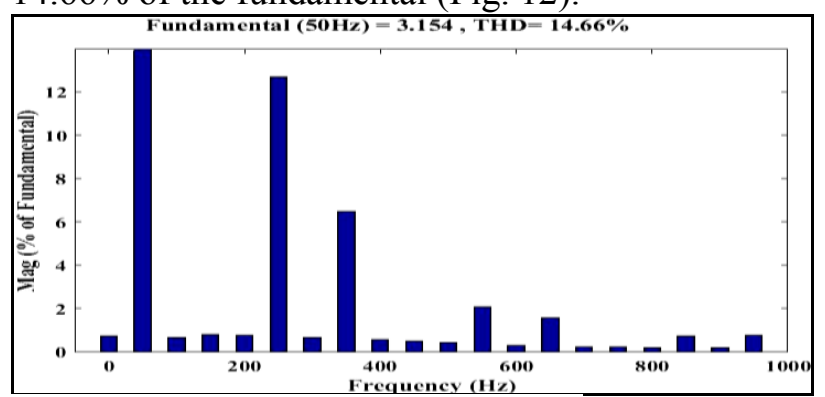

Fig.12. THD in Grid injected Current

Figure 13 illustrates the THD level of load voltage.

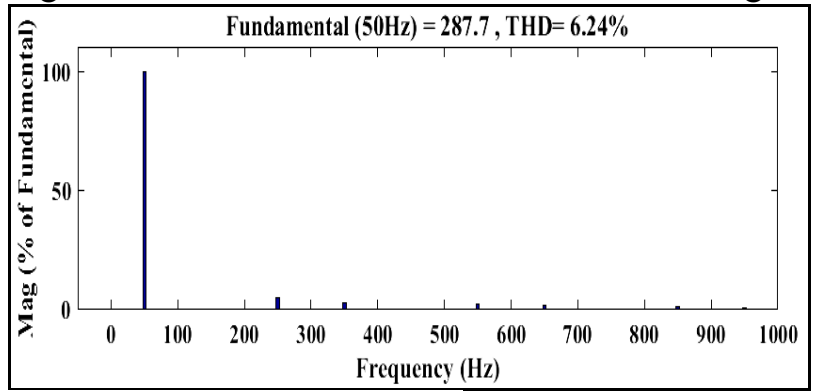

Fig.13. THD in Load Voltage

The RMS value of load voltage is $287.7 \mathrm{~V}$ with THD value 6.24 percent. Use of SCCS ensures the voltage and current waveforms as balanced and smoother. The PV output voltage and current are represented in figure 14 (a) and (b) respectively with a peak of $230 \mathrm{~V}$ load voltage and 2.341 A load peak current.

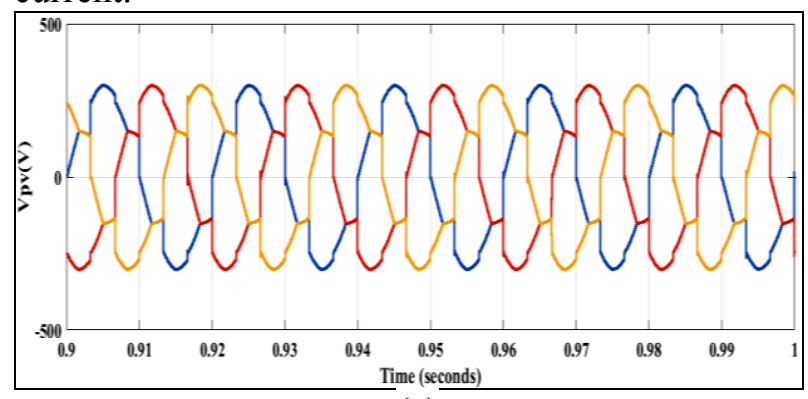

(a) 


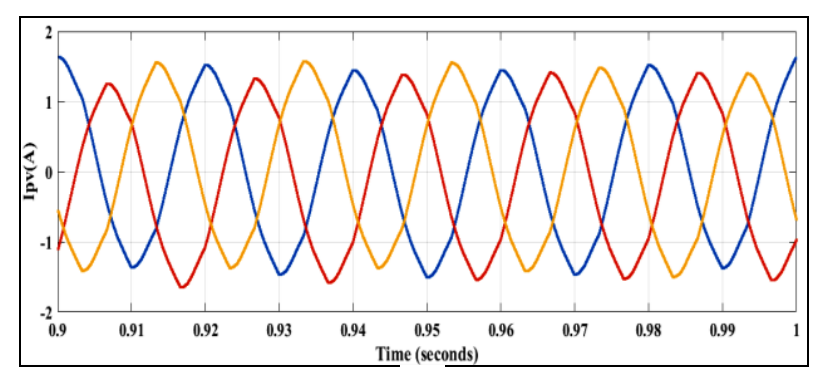

(b)

Fig.14. PV Inverter Output: (a) Voltage (b) Current

The figure 15(a) and 14(b) illustrates load voltage with a peak of $230 \mathrm{~V}$ and load current peak at $2.3 \mathrm{~A}$.

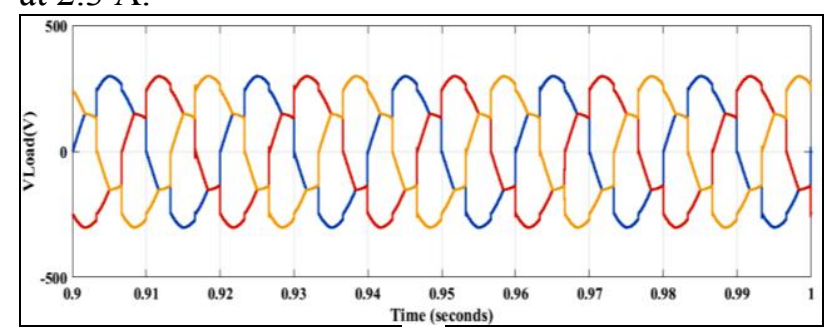

(a)

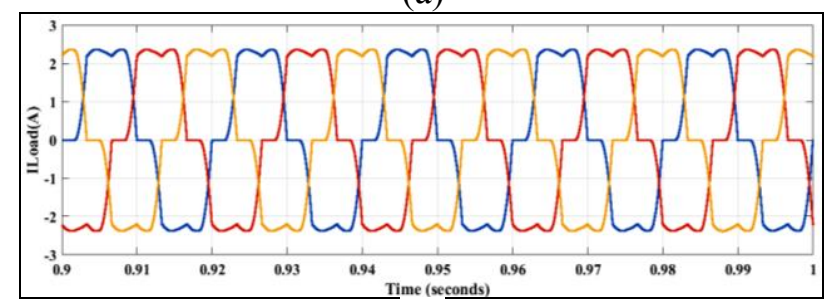

(b)

Fig.15. Load: (a) voltage (b) current

The harmonics observed in the voltage and current waveforms are to be mitigated by UPQC. The figure 16 illustrates the battery current showing negative indicates the charging of the battery.

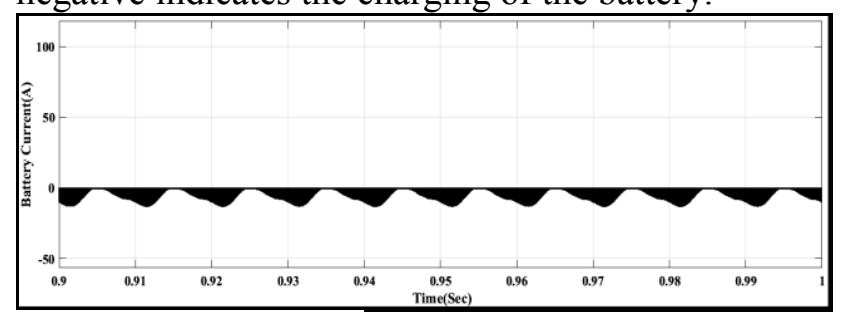

Fig.16 Battery Current

The figure 17 shows the supply of consistent current by the fuel cell (SOFC).

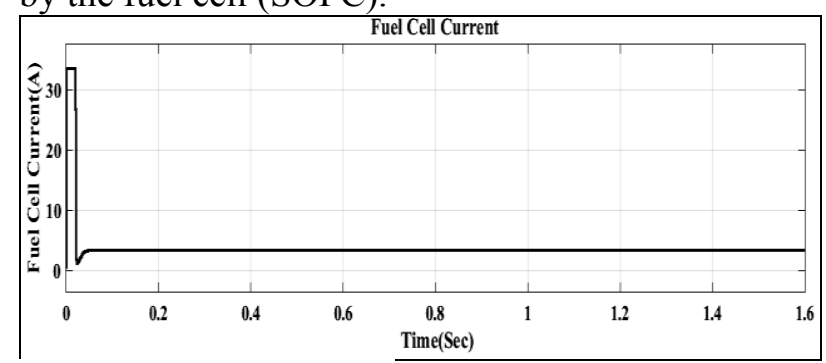

Fig.17 Fuel Cell Current

\subsection{Integrated PV with UPQC}

Numerous simulations were executed with the simulation parameters as mentioned in Table II.

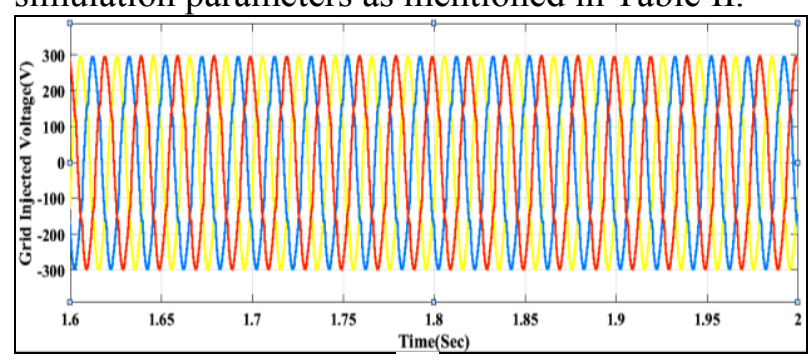

(a)

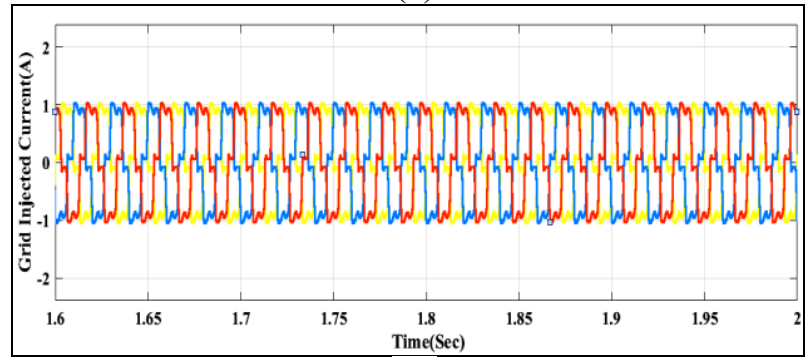

(b)

Fig.18. UPQC inserted signals (Supply end): (a) Voltage (b) Current

The figure 18 illustrates the UPQC shunt filter injected signals. Supplied phase voltage and behaviour of line current of the $3-\varphi 3 \mathrm{~W}$ system are illustrated in figure 18(a) and (b) respectively. It unveils the indemnity by the UPQC at source end ensuing grid insertions as sinusoidal. Figure 19 represents the VSC inverter output as fed by the Boost converter.

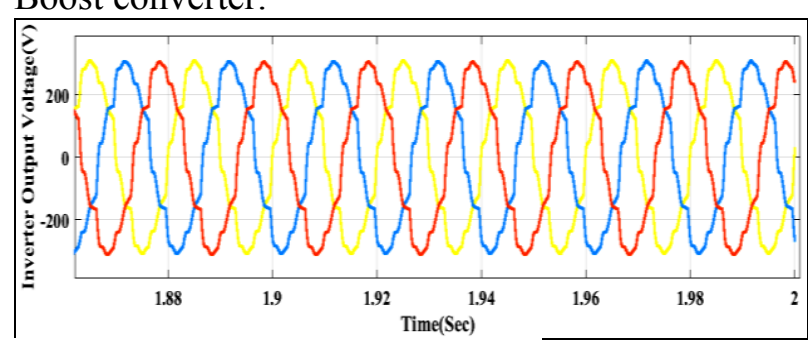

Fig.19. Inverter Output Waveform

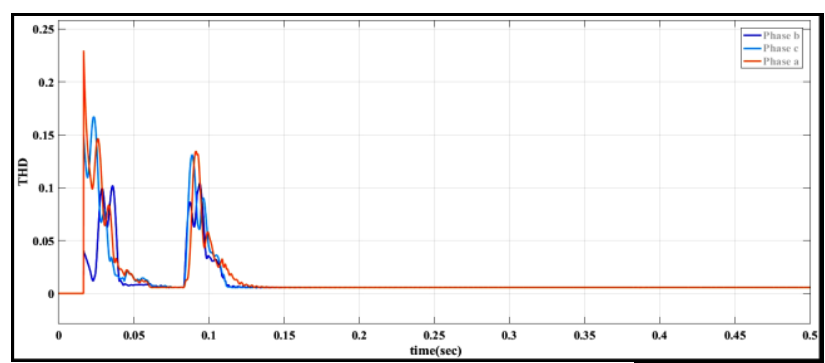

Fig.20. Total Harmonic Distortion Level

The VSC output of PV- Battery- Inverter system shows a 5 step voltage waveform with a peak of $300 \mathrm{~V}$. The load voltage is distorted and unbalanced 
prior to any indemnity, but SCCS based UPQC ensures substantial improved in load voltage. The THD for individual supply phase current (figure 20) is found to be about $0.6 \%$.

\subsection{Standalone PV System}

The stand-alone PV has been considered to study and observe its performance for every operating condition of UPQC with resistance $1 \Omega$ and Inductance $0.3 \mathrm{H}$ and operating frequency of the boost converter as $5 \mathrm{kHz}$. The figure 20 illustrates the UPQC shunt filter insertions of source voltage (Fig. 21(a)) and line current (Fig. 21(b)).

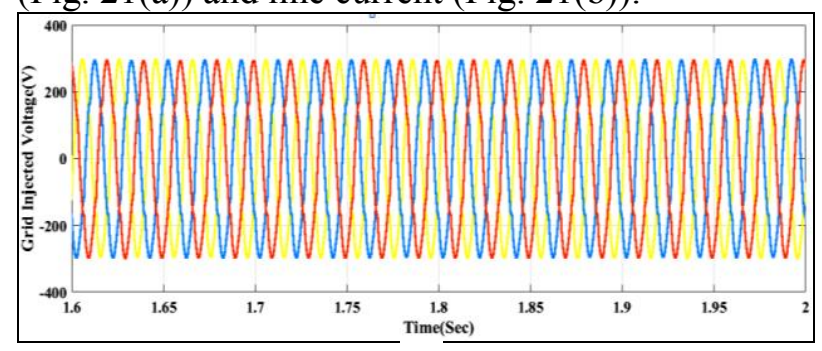

(a)

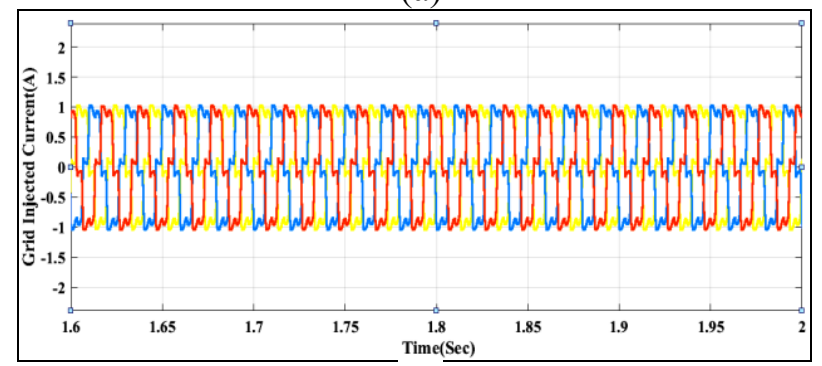

(b)

Fig.21. Source End: (a) Voltage (b) Current

These waveforms confess about the compensation of UPQC at the supply end. The THD level is illustrated in figure 22 .

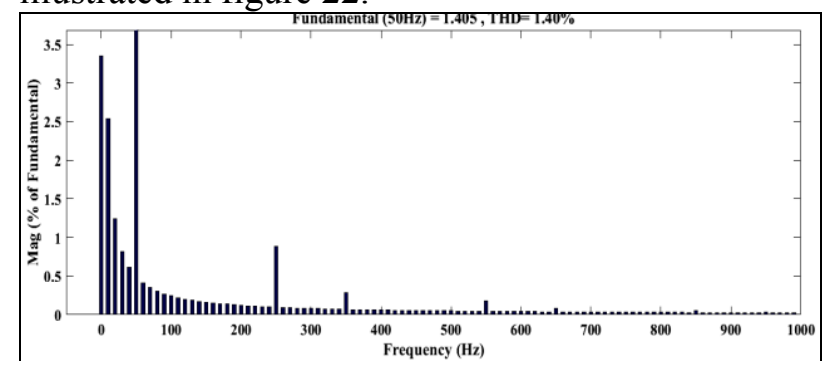

Fig.22. Total Harmonic Distortion (THD) in Standalone PV System

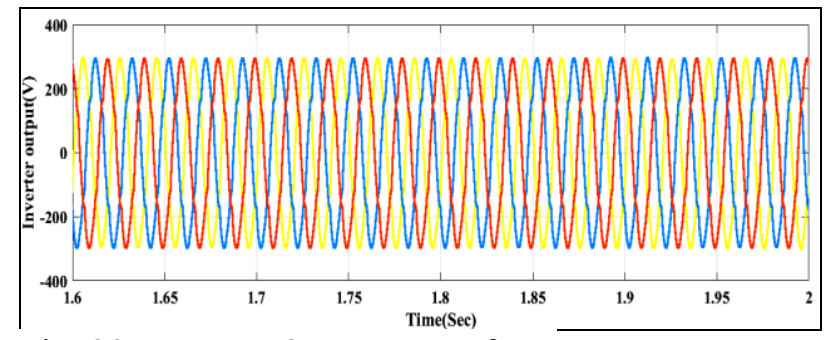

Fig. 23. Inverter Output Waveform
The figure 21(b) reveals that the current drawn from source is sinusoidal with a peak $1.405 \mathrm{~A}$ indicating the current through UPQC is small, and is able to reduce the harmonic content of source current. The figure 23 presents the VSC inverter output from the Boost converter.

The inverter output voltage of the hybrid system has a peak value of $230 \mathrm{~V}$. The UPQC separates the harmonics present in the inverter output from the load end as presented in figure 21 and 22.

\subsection{Grid-Connected PV - FC $\boldsymbol{\mu}$-grid System}

Here, the operation of the UPQC in grid integrated PV-FC $\mu$-grid is simulated for a $3 \mathrm{P} 3 \mathrm{~W}$ system. The control circuitry is modeled for PV-FC systems in stand-alone and grid-integrated mode with the same circuitry conditions under constant and variable irradiance conditions. The four different cases discussed here are as follows:

A. Constant irradiance condition at $250 \mathrm{~W} / \mathrm{m}^{2}$.

B. Variable irradiance condition in which the variation in irradiance is simulated using signal builder.

C. The load is varied in which the irradiance is kept fixed.

D. Both the irradiance as well as the load is varied simultaneously.

All the above cases have been discussed with grid integration.

The figure 24 illustrates the block diagram.

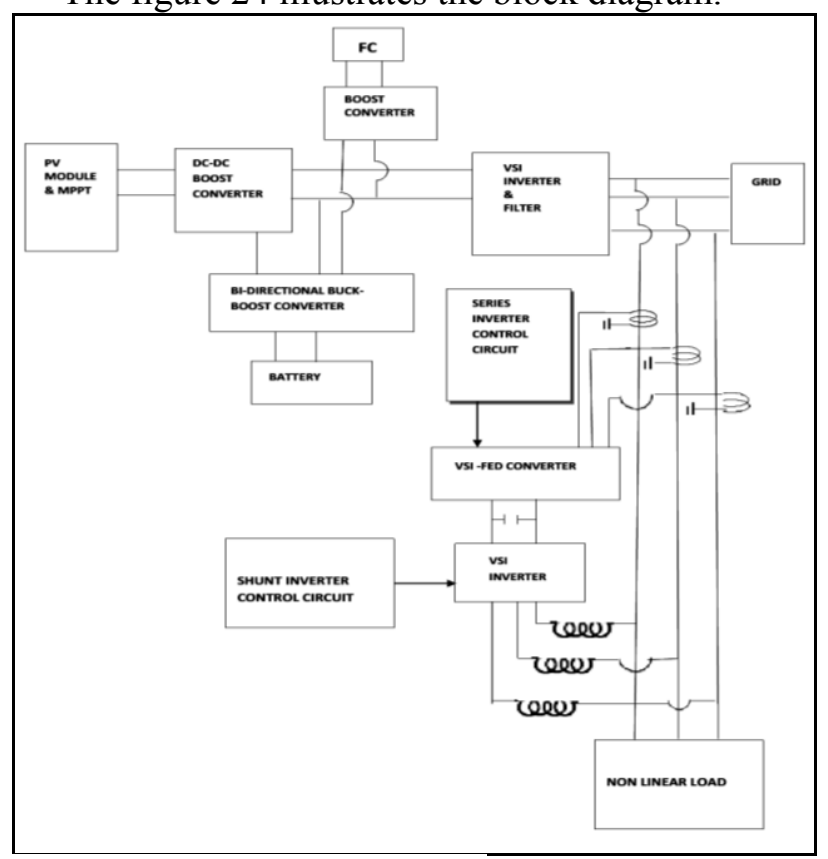

Fig.24. System Block Diagram

The boost converter steps up the DC voltage as produced by the PV source. A Proton exchange membrane FC (an energy system) has been attached to the point of common coupling (PCC) through the 
same boost converter. It has the capacity of highpower density with an advantage of low weight and volume. A Lead acid battery (storage system) due to its low cost and high energy density is connected to the PCC via a bidirectional buck-boost converter so that it can charge and discharge as per the necessity. The output of these sources is fed to a VSI inverter as discussed earlier. The output of the system is fed to a non-linear load and to grid. UPQC performance is studied with the variable PV output and load.

\subsubsection{Constant Irradiance Condition}

Under constant irradiance of $550 \mathrm{~W} / \mathrm{m}^{2}$ the grid injected voltage from PV-FC end is given in the figure 25 .

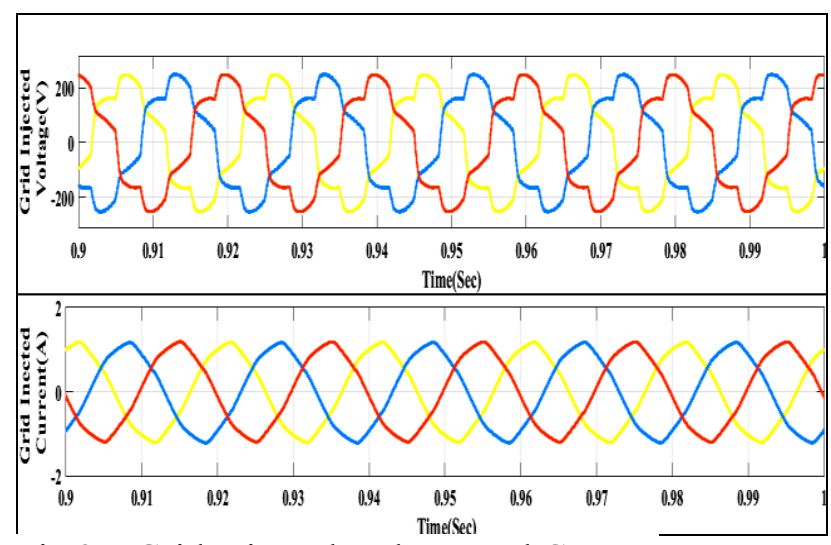

Fig.25. Grid Injected Voltage and Current

The grid inserted voltage has a peak value $230 \mathrm{~V}$ and current 1.149A provides a balanced AC voltage to the grid.

The figure 26 presents the balanced injected voltage and current of the UPQC shunt inverter in the load circuit.

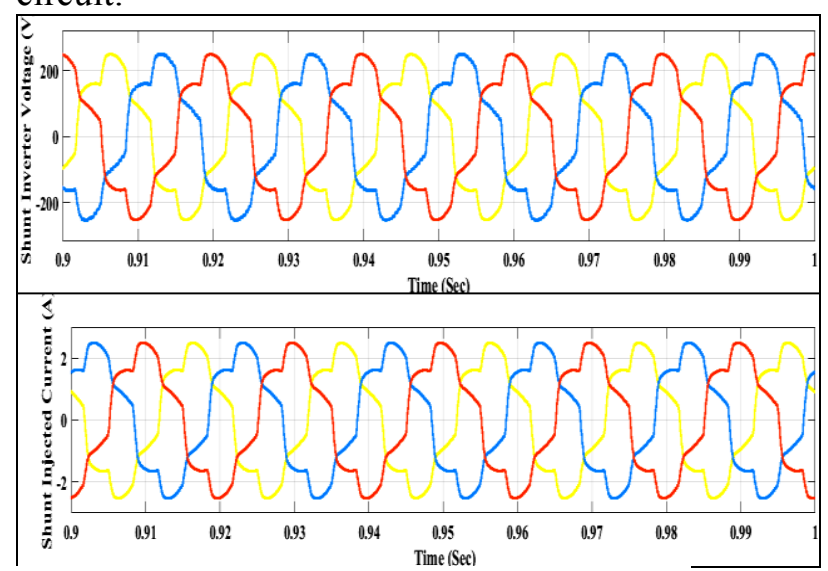

Fig.26. UPQC Injected Voltage and Current

The load voltage and current waveform of the 3- $\Phi$ nonlinear load is given in figure 27.

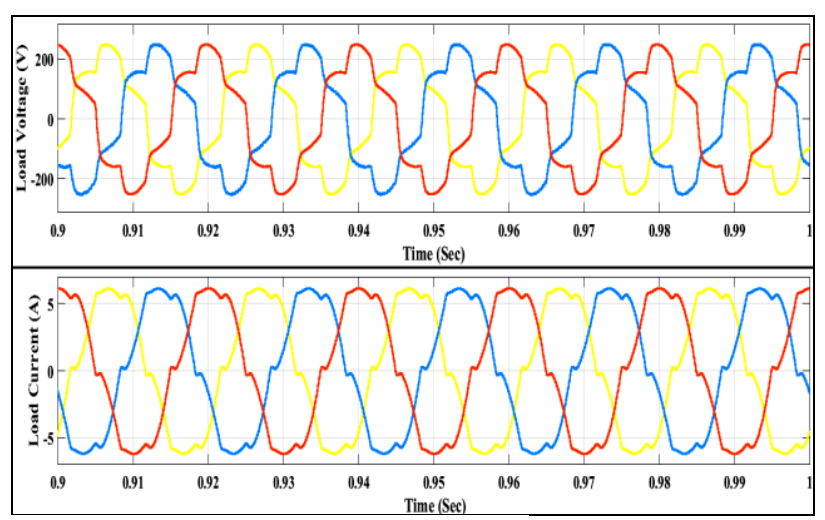

Fig.27. Load Voltage and Current

The load voltage has a peak of $234.1 \mathrm{~V}$ which is nearly $230 \mathrm{~V}$, due to shunt converter compensation of UPQC.

The load voltage THD is 5.92 percent with the linear load (Fig.28).

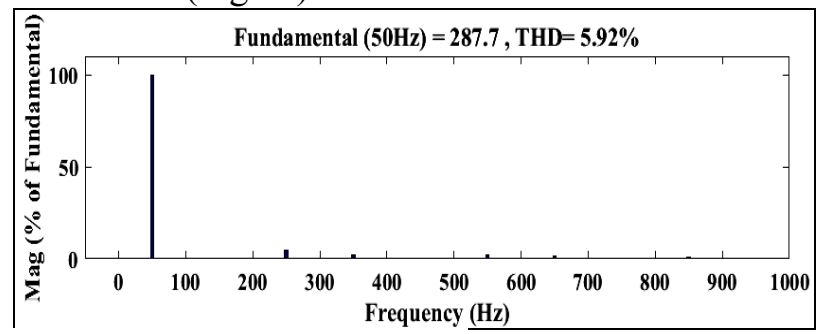

Fig.28. THD in Load Voltage

THD in source current is presented in figure 29.

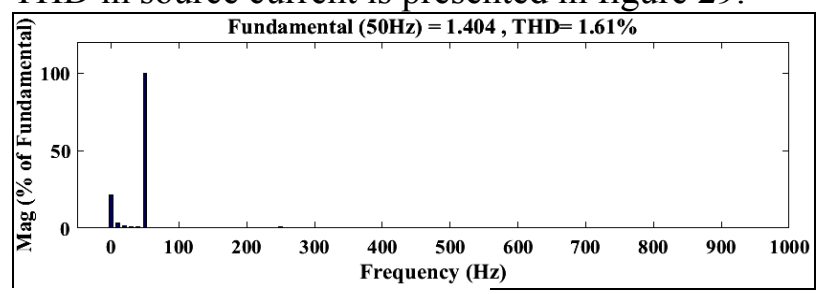

Fig.29. THD in Source Current

The source current fundamental has an RMS value of $287.7 \mathrm{~A}$ with a THD of 1.61 quite low as desired. The source current is near to fundamental as desired by SCCS. The presence of dominant harmonics (5th and 7 th) is less than $5 \%$ of the fundamental which validates the satisfactory performance of UPQC under SCCS.

\subsubsection{Variable Irradiance Condition}

Figure 29 presents the grid injected voltage and current under variable irradiance condition. A switching delay of 0.1 second is provided for the series converter so that there will be a voltage dip till the series converter is in action. After 0.1 second, breaker is closed with a voltage injection at the series transformer terminal for improvement of the voltage sketch which indicates the desired performance of the UPQC series converter. 


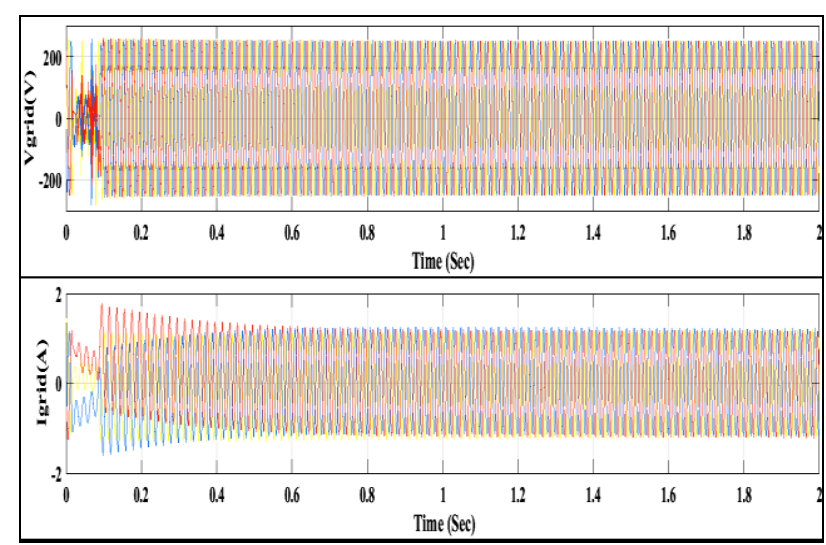

Fig.30. Grid Injected voltage and current with constant Load and Variable Irradiance

The grid injected voltage has a peak of $230 \mathrm{~V}$ with current has an RMS value of 1.134A. The figure 31 shows the UPQC compensated voltage and current.

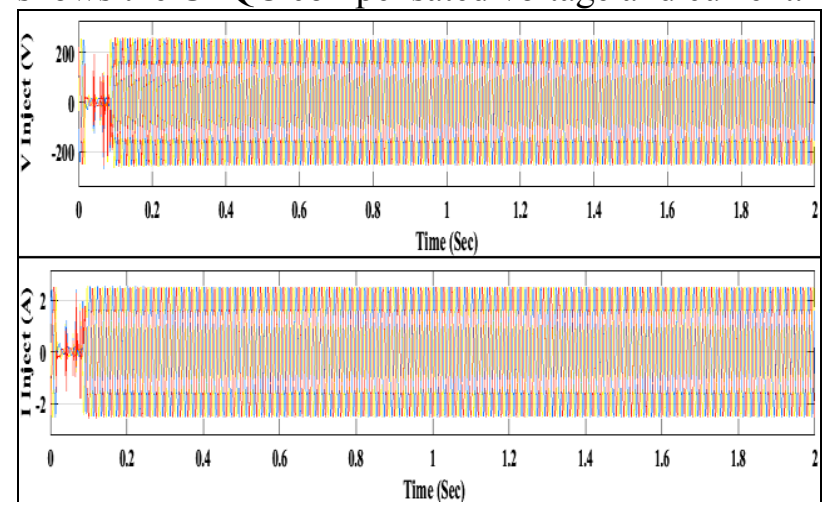

Fig.31. UPQC Injected Voltage and Current with constant Load and Variable Irradiance

The UPQC injects current at a phase voltage of $230 \mathrm{~V}$ peak. The per-phase value of the waveforms of the injected voltage and current are found to be sinusoidal and balanced.

Figure 32 presents the load voltage and current for the nonlinear load circuit.

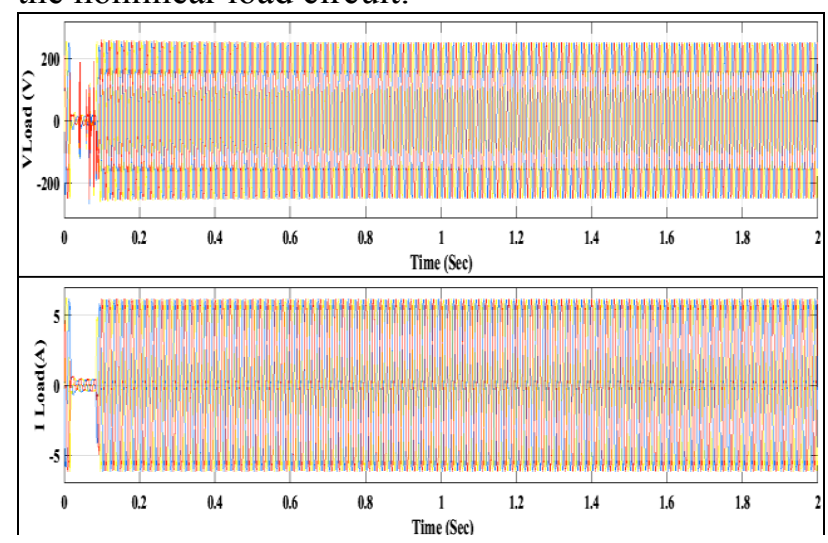

Fig.32. Load Voltage with constant Load and Variable Irradiance

A drop in the load voltage at non-linear load terminal is due to sudden switching of the load at
0.1 second. Due to the intervention of shunt converter control, the voltage is restored after 0.1 second. Under the mentioned operating condition, the source current is near to sinusoidal as desired in the SCCS. Figure 33 presents the THD of grid inserted current, i.e., $1.4 \%$ of the fundamental whereas figure 34 presents the THD of grid inserted voltage which is $6.24 \%$ of the fundamental.

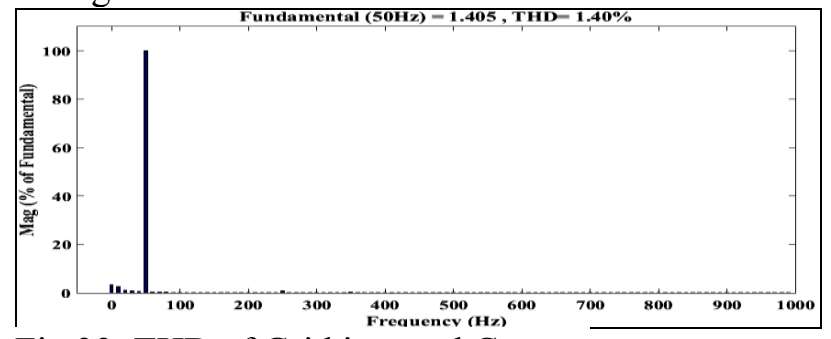

Fig.33. THD of Grid inserted Current

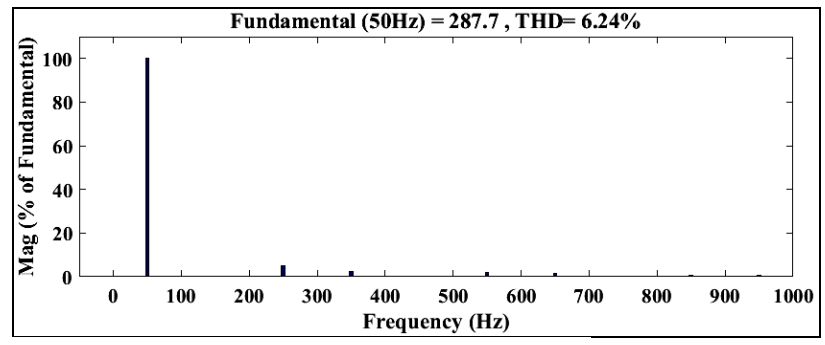

Fig.34. THD of Grid inserted Voltage

Similar to the grid injected current, the voltage have the traces of $5^{\text {th }}$ harmonic, but is insignificant.

\subsubsection{Constant Irradiance and Variable Load}

Under constant irradiance of $550 \mathrm{~W} / \mathrm{m}^{2}$, the load is varied after every 0.5 seconds. In these conditions irrespective of load variation, the grid injected voltage is observed as constant. Figure 35 presents grid injected voltage and current under this condition.

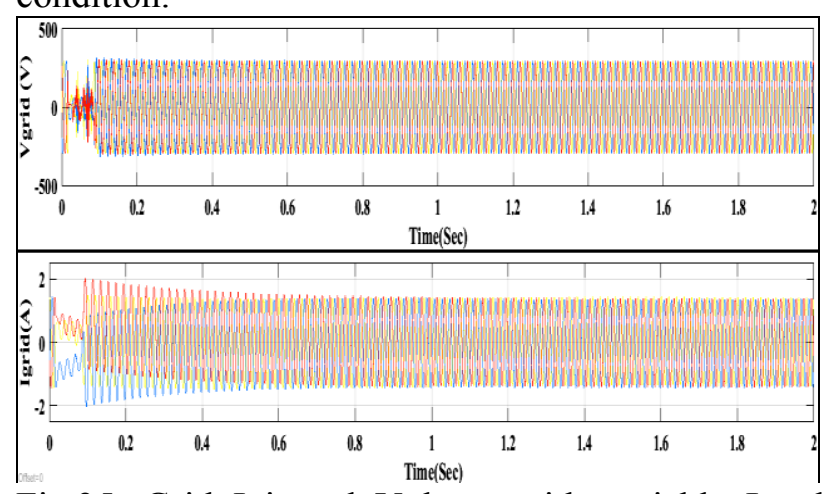

Fig.35. Grid Injected Voltage with variable Load and constant Irradiance

The grid injected voltage has a peak of $230 \mathrm{~V}$. The initial fluctuation is due to the switching of the breaker at 0.1 second. Figure 36 presents shunt inverter injected current and voltage of UPQC which are found to be sinusoidal and balanced. 


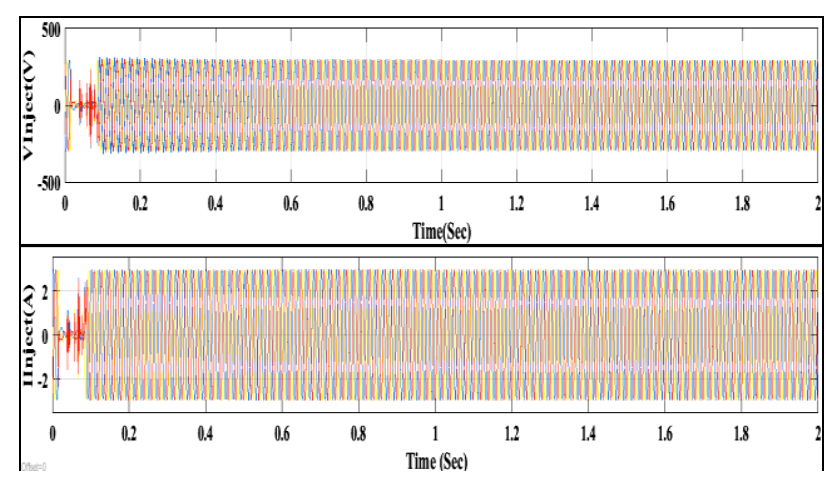

Fig.36. UPQC Injected Voltage with variable Load and constant Irradiance

Figure 37 presents load voltage and current for the nonlinear load circuit.

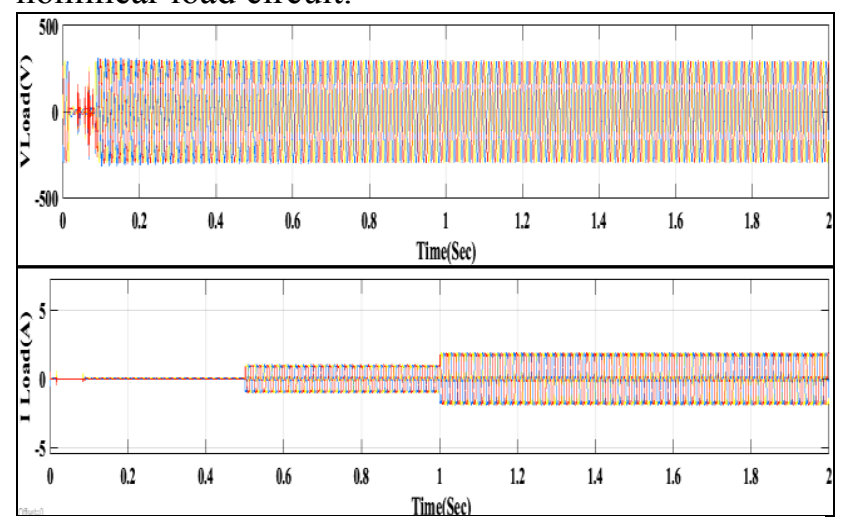

Fig.37. Load voltage and current with Variable Load and Constant Irradiance

Under the condition of constant irradiance and variable load, the source current is near to sinusoidal satisfying the SCCS. With the load variation, current drawn varies but from the above results, there is zero fluctuation in grid injected voltage and the UPQC supplied current implies as an extra amount of current drawn from the battery.

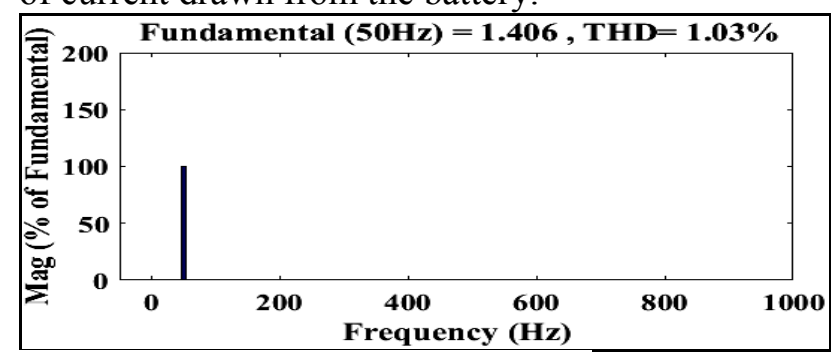

Fig.38. THD in Grid injected Current

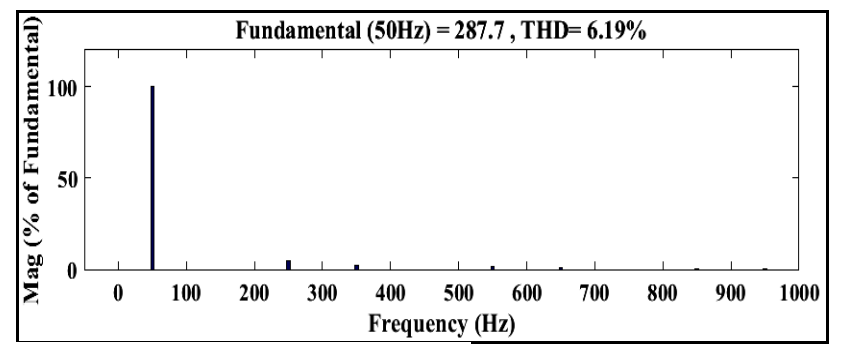

Fig.39. THD in Load Voltage
The figure 38 presents the THD of grid inserted current as $1.03 \%$ of fundamental with the RMS value $1.406 \mathrm{~A}$ of fundamental whereas figure 39 presents THD of grid inserted voltage as $6.19 \%$ of fundamental with the RMS value of $287.7 \mathrm{~V}$.

\subsubsection{Variable Irradiance and Variable Load}

Here after every 0.5 seconds, the irradiance and the load varies. The irradiance is $500 \mathrm{~W} / \mathrm{m}^{2}$ and reduced to $250 \mathrm{~W} / \mathrm{m}^{2}$ with the load is doubled. Under this condition, the sinusoidal and balanced grid injected voltage and current are illustrated in the figure 40 .

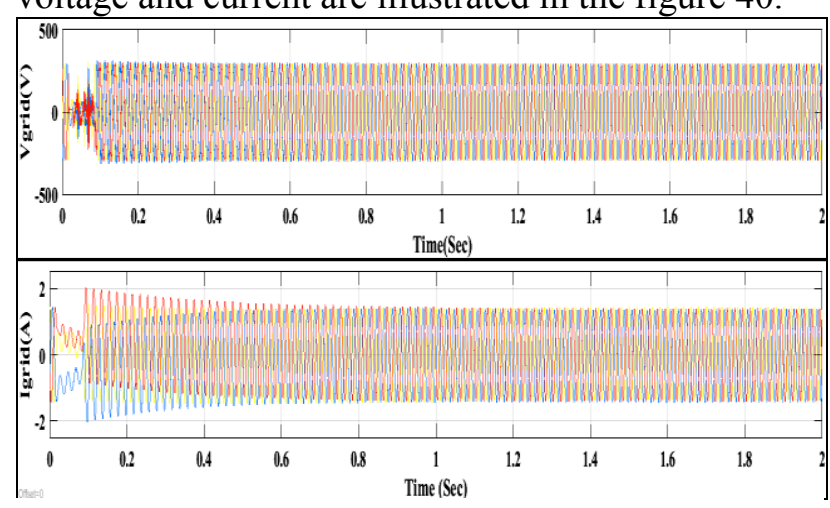

Fig.40. Grid injected Voltage and Current with Variable Load Variable Irradiance

The initial distortion for the first 0.1 second is due to the interpreted from $\mathrm{CB}$ operation as discussed earlier. Figure 41 represents the UPQC shunt inverter injected current and voltage.

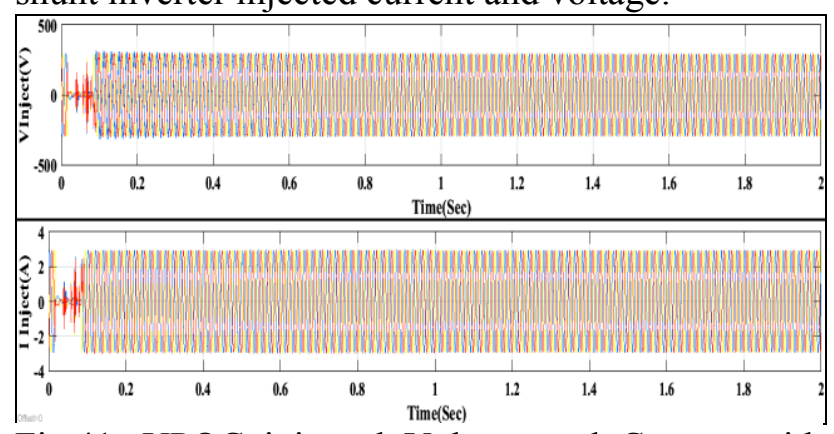

Fig.41. UPQC injected Voltage and Current with Variable Load and Variable Irradiance

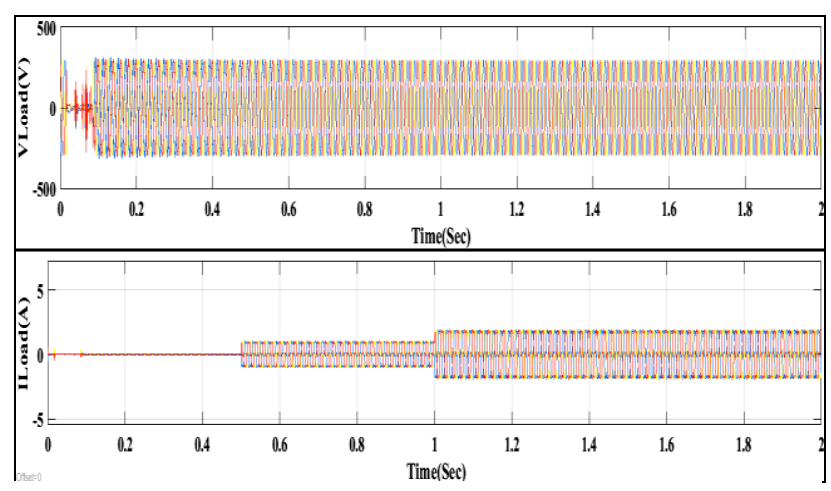

Fig.42. Load Voltage and Current with Variable Load and Variable Irradiance 
With the variation of load and irradiance, the grid voltage is constant. Besides the load voltage is maintained at $300 \mathrm{~V}$ peak which signifies the performance of the ShAF in maintaining the grid injected current and voltage with a satisfactory load voltage (Fig. 42).

The THD of grid injected current $1.05 \%$ of the fundamental with RMS value 1.406 A (Fig. 43) whereas THD of load voltage is $6.27 \%$ of the fundamental with RMS value 287.7 V (Fig.44).

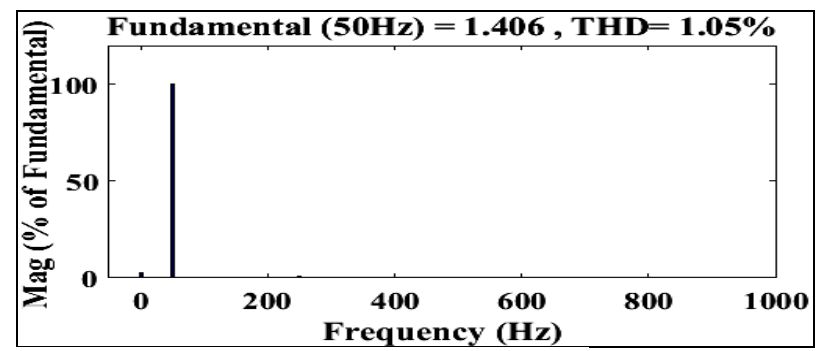

Fig.43. THD in Grid injected Current

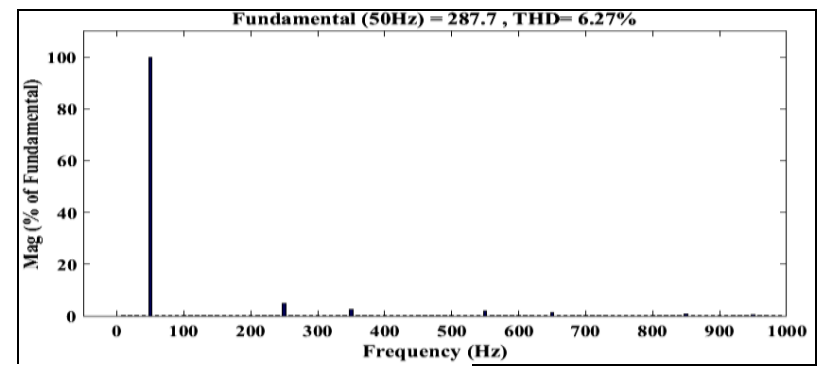

Fig.44. THD in Load Voltage

\section{Conclusion}

The conceptual study of the UPQC execution for a 3- $\varphi$ 3-Wire system has been carried out under simultaneous of non-linear and linear loading conditions along with several variable conditions like the irradiance and load. The UPQC is driven by the proposed SCCS allowing the source to draw constant sinusoids under steady state condition so that the grid injected current and the supply voltage approaches to be sinusoidal.

Additionally, four cases of PV-FC $\mu$-grid system have been studied. The UPQC control strategy performs well in all the conditions to mitigate the PQ disturbance owing to variation in irradiance or load. In case of load variations at an interval of 0.5 sec, have no impact on the load voltage or the voltage in the connected circuit, but a sudden rise in load leads to sag, and is mitigated by the UPQC. Similarly, load change has zero impact on grid injected voltage and the current inferring that with increase in load, an extra amount of power is fed by the battery. Meanwhile UPQC maintains the voltage profile by injecting voltage at the series transformer terminal of the series inverter significantly leaving behind an impression over satisfactory performance of UPQC in all conditions.

\section{Future Scope}

The proposed research work may further be extended in employing the similar techniques in the DG environment with 1- $\Phi$ system. The $\mu$-grid system so implemented can further be studied with different islanding conditions in coordination with CPDs to give reliable supply with islanding.

References:

[1] Akagi, H., "Trends in active power line conditioners,", IEEE Transactions on Power Electronics, vol.9, no.3, pp.263-268, May 1994.

[2] Senapati, R., Mishra, S. P., Senapati, R. N., \& Sharma, P. (2021). Power Quality Improvement of a 3-Phase-3-Wire Grid-Tied PV-Fuel Cell System by 3-Phase Active Filter Employing Sinusoidal Current Control Strategy. Microgrid Technologies, 329-376.

[3] Senapati, R., Senapati, R. N., \& Moharana, M. K. (2017). Sinusoidal current control strategy for UPQC in grid connected PV-fuel cell microgrid. International Journal of Engineering and Technology (IJET), 9(4), 2800-2813.

[4] Brenna, M.; Faranda, R.; Tironi, E., "A New Proposal for Power Quality and Custom Power Improvement: OPEN UPQC" , IEEE Transactions on Power Delivery, vol.24, no.4, pp.2107-2116, Oct. 2009.

[5] Mauricio Aredes, Jurgen Hafner, Klemens Heumann, "Three-Phase FourWire Shunt Active Filter Control Strategies," IEEE Transactions on Power Electronics, Vol. 12, No. 2, pp. 311-318, March 1997J. Clerk Maxwell, A Treatise on Electricity and Magnetism, 3rd ed., vol. 2. Oxford: Clarendon, 1892, pp.68-73.

[6] Koteswara Rao Uyyuru, Mahesh K. Mishra, and Arindam Ghosh, "An Optimization-Based Algorithm for Shunt Active," IEEE Transactions on Power Electronics, Vol. 24, No. 5, pp. 1223-1232, May 2009.

[7] Habi, M. Bouguerra, D. Ouahdi, and H. Meglouli, "Using the Schunt Active Power Filter for Compensation of the Distorted and Unbalanced Power System Voltage," World Academy of Science, Engineering and Technology, Vol. 24, pp. 152-156, 2006.

[8] T.Sopapirm, K-N.Areerak, K-L.Areerak, A.Srikaew, "The Application of Adaptive Tabu Search Algorithm and Averaging Model to the 
Optimal Controller Design of Buck Converters," World Academy of Science, Engineering and Technology, Volume 60, pp. 477-483, 2011.

[9] K.Chaijarurnudomrung, K-N.Areerak, KL.Areerak, and A.Srikaew, "The Controller Design of Three-Phase Controlled Rectifier Using an Adaptive Tabu Search Algorithm," Proceedings of 8th Electrical Engineering/ Electronics, Computer, Telecommunications and Information Technology (ECTI), Thailand, 2011, pp.605- 608.

[10] K-N.Areerak, S.V.Bozhko, G.M.Asher, and D.W. P.Thomas, "DQTransformation Approach for Modelling and Stability Analysis of AC-DC Power System with Controlled PWM Rectifier and Constant Power Loads," Proceedings of 13th International Power Electronics and Motion Control Conference (EPE-PEMC 2008), 2008,pp. 2049-2054.

[11] T.Kulworawanichpong, K-L.Areerak, KN.Areerak, and S.Sujitjorn, "Harmonic Identification for Active Power Filters Via Adaptive Tabu Search Method," LNCS (Lecture Notes in Computer Science), SpringerVerlag Heidelberg, Volume 3215, 2004, pp. 687-694.

[12] D.Puangdownreong, K-N.Areerak, A.Srikaew, S.Sujijorn, and P.Totarong, "System Identification via Adaptive Tabu Search," Proceedings of IEEE International Conference on Industrial Technology (ICIT02), 2002, pp. 915-920.

[13] Ghosh, Arindam, and Gerard Ledwich. Power quality enhancement using custom power devices. Springer Science \& Business Media, 2012.

[14] Roldán-Pérez, Javier, et al. "On the Power Flow Limits and Control in Series-Connected Custom Power Devices." IEEE Transactions on Power Electronics 31.10 (2016): 73287338.

[15] Ghosh, Arindam, and Gerard Ledwich. Power quality enhancement using custom power devices. Springer Science \& Business Media, 2012.

[16] Hingorani, N. G. (1995). Introducing custom power. IEEE spectrum, 32(6), 41-48.

[17] X. Han, R. Cheng, P. Wang \& Y. Jia, "Advanced dynamic voltage restorer to improve power quality in Microgrid", In Power and Energy Society General Meeting (PES), 2013 IEEE, pp. 1-5, July 2013.

[18] R. G. Wandhare, S. Thale, and V. Agarwal, "Reconfigurable hierarchical control of a
Microgrid developed with PV, wind, microhydro, fuel cell and ultra-capacitor," Conf. Proc. - IEEE Appl. Power Electron. Conf. Expo. - APEC, pp. 2799-2806, 2013.

[19] M. U. Tomal and H. A. Gabbar, "Key Performance Assessment of Fuel Cell Based Distributed Energy Generation System in Resilient Micro Energy Grid," IEEE Int. Conf. Smart Energy Grid Eng., pp. 1-6, 2015.

[20] P. Nayak, J. M. Patnaik \& R. K. Mallick, "Harmonics reckoning in micro grid using Kalman and weighted Kalman Filter Algorithm", In 2015 International Conference on Electrical, Electronics, Signals, Communication and Optimization (EESCO), January 2015.

[21] S. Rafiei, A. Moallem, A. Bakhshai, and D. Yazdani, "Application of a digital ANF based power processor for micro-grids power quality enhancement," Conf. Proc. - IEEE Appl. Power Electron. Conf. Expo. - APEC, pp. 3055-3059, 2014.

[22] A. Shahid and H. Azhar, "A modular control design for optimum harmonic compensation in micro-grids considering active and reactive power sharing," Proc. Int. Conf. Harmon. Qual. Power, ICHQP, pp. 601-605, 2014.

[23] S. Dhar and P. K. Dash, "Performance analysis of a new fast negative sequence power injection oriented islanding detection technique for photovoltaic photo-voltaic based voltage source converter based micro grid operation," IET Gener. Transm. Distrib., vol. 9, no. 15, pp. 2079-2090, 2015.

[24] S. K. Khadem, M. Basu \& M. F. Conlon, "A new placement and integration method of UPQC to improve the power quality in DG network", In Power Engineering Conference (UPEC), $2013 \quad 48$ th International Universities' (pp. 1-6), IEEE, 2013, September.

[25] R. Effatnejad, K. Choopani \& M. Effatnejad, "Designing the parallel active filter for improvement of the power quality in microgrids", in Industrial Informatics and Computer Systems (CIICS), 2016 International Conference, pp. 1-5, March, 2016.

[26] R. R. Sankar, S. D. Prasad \& K. S. Kumar, "Power quality improving using a voltage source converter", in 2015 International Conference on Electrical, Electronics, Signals, Communication and Optimization (EESCO), January 2015.

[27] R. W. Mosobi, T. Chichi, \& S. Gao, "Modeling and power quality analysis of integrated renewable energy system", in Power Systems 
Conference (NPSC), 2014 Eighteenth National, pp. 1-6, December, 2014.

[28] V. Khadkikar, A. Chandra, A. O. Barry and T.D. Nguyen, "Conceptual Study of Unified Power Quality Conditioner (UPQC)," in Industrial Electronics, 2006 IEEE International Symposium on, vol.2, no., pp.1088-1093, 9-13 July 2006.

[29] V. Khadkikar, A. Chandra, A.O. Barry and T.D. Nguyen, "Power quality enhancement utilising single-phase unified power quality conditioner: digital signal processor-based experimental validation" Conference on Power Electronics, Vol. 4, Page(s): 323 -331, 2011.

[30] V. Khadkikar, A. Chandra, A. O. Barry and T. D. Nguyen "Analysis of Power Flow in UPQC during Voltage Sag and Swell Conditions for Selection of Device Ratings", Canadian Conference on Electrical and Computer Engineering, Montreal, Page(s): 867 -872, May 2006.

[31] R.V.D. Rama Rao, Subhransu and Sekhar Dash, "Power Quality Enhancement by Unified Power Quality Conditioner Using ANN with Hysteresis Control" International Journal of Computer Applications (0975 - 8887) Vol. 6, Page(s): 9-15, Sep. 2010.

[32] D. O. Kisck and V. Navral, "Quality Conditioner with Optimum Voltage Angle Injection," vol. 00, pp. 2443-2448, 1980.

[33] H. Fujita \& H. Akagi, "The unified power quality conditioner: the integration of seriesand shunt-active filters", IEEE transactions on power electronics, vol. 13, no. 2, pp. 315-322, 1998.

[34] M. Vilathgamuwa, Y. H. Zhang \& S. S. Choi, "Modelling, analysis and control of unified power quality conditioner", in Harmonics and Quality of Power Proceedings, 1998 Proceedings. 8th International Conference, Vol. 2, pp. 1035-1040, IEEE,1998, October.

[35] Y. Chen, X. Zha, J. Wang, H. Liu, J. Sun \& H. Tang, "Unified power quality conditioner (UPQC): The theory, modeling and application", in Power System Technology, 2000. Proceedings. PowerCon 2000, International Conference on (Vol. 3, pp. 13291333). IEEE. 2000.

[36] M. Hu \& H. Chen, "Modeling and controlling of unified power quality compensator", 2000.

[37] A. Elnady \& M. M. A. Salama, "New functionalities of the unified power quality conditioner", in Transmission and Distribution Conference and Exposition, 2001 IEEE/PES (Vol. 1, pp. 415-420), IEEE, 2001.
[38] M. Basu, S. P. Das \& G. K. Dubey, "Performance study of UPQC-Q for load compensation and voltage sag mitigation", in IECON 02 [Industrial Electronics Society, IEEE 2002 28th Annual Conference, (Vol. 1, pp. 698-703), IEEE, 2002, November.

[39] M. T. Haque, T. Ise \& S. H. Hosseini, "A novel control strategy for unified power quality conditioner (UPQC)", in Power Electronics Specialists Conference, 2002. pesc 02. 2002 IEEE 33rd Annual (Vol. 1, pp. 94-98), IEEE, 2002.

[40] R. Faranda \& I. Valade, "UPQC compensation strategy and design aimed at reducing losses", in Proc. IEEE ISIE (Vol. 4, pp. 1264-1270), 2002, July.

[41] G. Jianjun, X. Dianguo, L. Hankui \& G. Maozhong, "Unified power quality conditioner (UPQC): the principle, control and application", in Power Conversion Conference, 2002. PCC-Osaka 2002. Proceedings of the (Vol. 1, pp. 80-85), IEEE, 2002

[42] L. H. Tey, P. L. So \& Y. C. Chu, "Neural network-controlled unified power quality conditioner for system harmonics compensation", in Transmission and Distribution Conference and Exhibition 2002: Asia Pacific. IEEE/PES (Vol. 2, pp. 10381043), IEEE, 2002, October.

[43] J. M. Correa, S. Chakraborty, M. G. Simoes \& F. A. Farret, "A single phase high frequency AC microgrid with an unified power quality conditioner", in Industry Applications Conference, 2003, 38th IAS Annual Meeting. Conference Record of the (Vol. 2, pp. 956962), IEEE, 2003, October.

[44] A. Ghosh, A. K. Jindal \& A. Joshi, "Inverter control using output feedback for power compensating devices", in TENCON 2003. Conference on Convergent Technologies for the Asia-Pacific Region (Vol. 1, pp. 48-52), IEEE, 2003, October.

[45] L. F. Monteiro, M. Aredes \& J. M. Neto, "A control strategy for unified power quality conditioner", in Industrial Electronics, 2003, ISIE'03, 2003 IEEE International Symposium on (Vol. 1, pp. 391-396), IEEE, 2003, June.

[46] A. Nasiri \& A. Emadi, "Different topologies for single-phase unified power quality conditioners", in Industry Applications Conference, 2003, 38th IAS Annual Meeting, Conference Record of the (Vol. 2, pp. 976981), IEEE, 2003, October.

[47] G. Chen, Y. Chen, L. F. Sanchez \& K. M. Smedley, "Unified power quality conditioner 
for distribution system without reference calculations", in Power Electronics and Motion Control Conference, 2004, IPEMC 2004, The 4th International (Vol. 3, pp. 1201-1206), IEEE, 2004, August.

[48] D. W. Keith, J. F. DeCarolis, D. C. Denkenberger, D. H. Lenschow, S. L. Malyshev, S. Pacala \& P. J. Rasch, "The influence of large-scale wind power on global climate", Proceedings of the national academy of sciences of the United States of America, vol. 101, no. 46, pp. 16115-16120, 2004.

[49] A. Ghosh, A. K. Jindal \& A. Joshi, "A unified power quality conditioner for voltage regulation of critical load bus", in Power Engineering Society General Meeting, 2004, IEEE, (pp. 471-476), 2004, June.

[50] V. Khadkikar, P. Agarwal, A. Chandra, A. O. Barry \& T. D. Nguyen, "A simple new control technique for unified power quality conditioner (UPQC)", in Harmonics and Quality of Power, 2004. 11th International Conference on (pp. 289-293), IEEE, 2004, September.

[51] C. A. Sepúlveda, J. R. Espinoza, L. A. Morán \& R. Ortega, "Analysis and design of a linear control strategy for three-phase UPQCs", in Industrial Electronics Society, 2004. IECON 2004. 30th Annual Conference of IEEE (Vol. 3, pp. 3060-3065), IEEE, 2004, November.

[52] M. Aredes, J. A. Moor, J. C. C. Ferreira, L. F. C. Monteiro, R. M. Fernandes \& M. J. V. Siqueira, "A simplified control strategy for a unified power quality conditioner prototype", in Power Electronics Specialists Conference, 2005, PESC'05, IEEE 36th (pp. 2592-2597), IEEE, 2005, June.

[53] J. M. Correa, F. A. Farret \& M. G. Simoes, "Application of a modified single-phase PQ Theory in the control of shunt and series active filters in a $400 \mathrm{~Hz}$ microgrid", in Power Electronics Specialists Conference, 2005, PESC'05. IEEE 36th (pp. 2585-2591), IEEE, 2005, June.

[54] S. Hongchun, L. Zuquan, Y. Jilai and X. Liang, "A Novel Control Strategy for UPQC", 2005 IEEE/PES Transm. Distrib. Conf. Expo, Asia Pacific, pp. 1-4, 2005.

[55] V. Khadkikar, A. Chandra, A. O. Barry \& T. D. Nguyen, "Steady state power flow analysis of unified power quality conditioner (UPQC)", in Industrial Electronics and Control Applications, 2005, ICIECA 2005. International Conference on (pp. 6-pp), IEEE, 2005, December.
[56] J. R. Reyes, J. R. Espinoza \& C. A. Sepúlveda, "Operating region of single-phase UPQCs", in Power Electronics Specialists Conference, 2005, PESC'05, IEEE 36th (pp. 1726-1731), IEEE, 2005, June.

[57] A. Kazemi, M. Sarlak \& M. Barkhordary, "An adaptive noise canceling method for singlephase unified power quality conditioner", in Industrial Electronics and Applications, 2006 1ST IEEE Conference on (pp. 1-6), IEEE, 2006, May.

[58] V. Khadkikar, A. Chandra, A. O. Barry \& T. D. Nguyen, "Application of UPQC to protect a sensitive load on a polluted distribution network", in Power Engineering Society General Meeting, 2006, IEEE (pp. 6-pp), IEEE, 2006, June.

[59] A. J. Laxmi, G. T. R. Das, K. U. Rao, K. Sreekanthi \& K. Rayudu, "Different control strategies for Unified Power Quality Conditioner at load side", in Industrial Electronics and Applications, 2006 1ST IEEE Conference on (pp. 1-7), IEEE, 2006, May.

[60] P. Li, Q. Bai \& G. Li, "Coordinated control strategy for UPQC and its verification", in Power Engineering Society General Meeting, 2006, IEEE (pp. 8-pp), IEEE, 2006, June.

[61] T. Zhili, L. Xun, C. Jian, K. Yong \& D. Shanxu, "A direct control strategy for UPQC in three-phase four-wire system", in Power Electronics and Motion Control Conference, 2006, IPEMC 2006, CES/IEEE 5th International (Vol. 2, pp. 1-5), IEEE, 2006, August.

[62] I. Axente, M. Basu \& M. F. Conlon, "A control approach for UPQC connected to weak supply point", in Universities Power Engineering Conference, 2007, UPEC 2007, 42nd International (pp. 619-623), IEEE, 2007, September.

[63] H. Fujita \& H. Akagi, "The integration of series active filters and shunt active filters", IEEE Power Electronics Specialists Conference, vol. 1, pp. 494-501, 1996.

[64] G. Jianjun, X. Dianguo, L. Hankui \& G. Maozhong, "Unified power quality conditioner (UPQC): the principle, control and application", in Power Conversion Conference, 2002. PCC-Osaka 2002. Proceedings of the (Vol. 1, pp. 80-85), IEEE, 2002.

[65] I. Axente, J. N. Ganesh, M. Basu, M. F. Conlon \& K. Gaughan, "A 12-kVA DSPcontrolled laboratory prototype UPQC capable of mitigating unbalance in source voltage and 
load current", IEEE Transactions on power Electronics, vol. 25, no. 6, pp. 1471-1479, 2010.

[66] F. Ng, M. C. Wong \& Y. D. Han, "Analysis and control of UPQC and its DC-link power by use of pqr instantaneous power theory", In Power Electronics Systems and Applications, 2004, Proceedings, 2004 First International Conference on (pp. 43-53). IEEE, 2004, November.

[67] A. Kazemi, A. Mokhtarpour \& M. T. Haque, "A new control strategy for unified power quality conditioner (UPQC) in distribution systems", in Power System Technology, 2006, PowerCon 2006, International Conference on (pp. 1-5), IEEE. 2006, October.

[68] M. Hojo \& T. Funabashi, "Unified power quality conditioner for dynamic voltage restoration and fault current limitation", in Harmonics and Quality of Power, 2008, ICHQP 2008, 13th International Conference on (pp. 1-5), IEEE, 2008, September.

[69] Senapati, R., 2018. Study and analysis of performance of 3-phase shunt active filter in grid-tied pv-fuel cell system employing sinusoidal current control strategy. International Journal of Renewable Energy Research (IJRER), 8(1), pp.67-81.

[70] Senapati, R., Sahoo, R.K., Senapati, R.N. and Panda, P.C., 2016, March. Performance evaluation of Sinusoidal current control strategy unified Power Quality Conditioner. In 2016 International Conference on Electrical, Electronics, and Optimization Techniques (ICEEOT) (pp. 1404-1408). IEEE.

[71] Senapati, R., Senapati, R.N., Behera, P. and Moharana, M.K., 2016, October. Performance analysis of unified power quality conditioner in a grid connected PV system. In 2016 International conference on signal processing, communication, power and embedded system (SCOPES) (pp. 416-420). IEEE.

[72] Senapati, R., Mishra, S.P., Senapati, R.N. and Sharma, P., 2021. Power Quality Improvement of a 3-Phase-3-Wire Grid-Tied PV-Fuel Cell System by 3-Phase Active Filter Employing Sinusoidal Current Control Strategy. Microgrid Technologies, pp.329-376.

[73] Senapati, R., Senapati, R. N., \& Moharana, M. K. (2017). Sinusoidal Current Control Strategy for UPQC in Grid Connected PV-Fuel Cell Microgrid. International Journal of Engineering and Technology (IJET), 9(4), 2800-2813.

[74] Singh, Bhim; Al-Haddad, K.; Chandra, A., "A review of active filters for power quality improvement", IEEE Transactions on Industrial Electronics, vol.46, no.5, pp.960971, Oct 1999.

[75] Senapati, R. N., Sahoo, R. K., Senapati, R., \& Pradhan, P. (2016, July). Design and analysis of Sliding Mode Controller for Isolated Full Bridge DC-DC converter. In 2016 IEEE 1st International Conference on Power Electronics, Intelligent Control and Energy Systems (ICPEICES) (pp. 1-6). IEEE.

[76] M. $\mathrm{Hu}$ and $\mathrm{H}$. Chen, "Modelling and controlling of unified power quality conditioner", Proc. Adv. Power Syst. Control, Operation Management, Oct. 30-Nov. 1, 2000.

[77] Senapati, R., Sahoo, R.K., Pradhan, S. and Senapati, R.N., 2017, August. Sinusoidal current control strategy for 3-phase shunt active filter in grid-tied PV system. In 2017 International conference on energy, communication, data analytics and soft computing (ICECDS) (pp. 1272-1277). IEEE.

[78] Senapati, R. and Senapati, R.N., 2019. Performance evaluation of 3-phase series active filter in a grid tied PV-system employing sinusoidal current control strategy. International Journal of Innovative Technology and Exploring Engineering (IJITEE), 8(11), pp.1244-1252.

[79] Senapati, R., Mishra, S.P., Illa, V. and Senapati, R.N., 2020. Improvement of the Current Profile in Grid-Tied Hybrid Energy System by Three-Phase Shunt Active Filter. Innovation in Electrical Power Engineering, Communication, and Computing Technology, pp.45-60.

[80] Senapati, R., Illa, V., Swain, S.C. and Senapati, R.N., 2021. Voltage and current profile improvement of a PV-integrated grid system employing sinusoidal current control strategy based unified power quality conditioner. Materials Today: Proceedings, 39, pp.1866-1875.

[81] Sharma, P., Das, S., Senapati, R., Mishra, S.P. and Senapati, R.N., 2020, September. Performance Evaluation of PV-SOFC Grid Integrated 3P3W System by UPQC with Sinusoidal Current Control Strategy at Constant Irradiance. In 2020 IEEEHYDCON (pp. 1-6). IEEE.

[82] Mahmoud M.S. Al-Suod, Ushkarenko Oleksandr, "Optimization of the Speed Controller in Gas Diesel Device Including in the Autonomous Electric Power System", WSEAS Transactions on Circuits and Systems, vol. 18, pp. 135-140, 2019. 
[83] Osama Elbaksawi, "Hybrid Control for Power System Based on STATCOM and UPFC with Two 3-level 48-pulse under Different Conditions", WSEAS Transactions on Circuits and Systems, vol. 19, pp. 277-288, 2020

\section{Author Contributions:}

Vamsi Ram Illa has carried out the simulation and result analysis.

Rudranarayan Senapati has conceptualised the SCCS and its application to UPQC and presented the review section.

Sarat Chandra Swain has organized the entire manuscript.

\section{Creative Commons Attribution License 4.0 (Attribution 4.0 International, CC BY 4.0)}

This article is published under the terms of the Creative Commons Attribution License 4.0

https://creativecommons.org/licenses/by/4.0/deed.en_US 